\title{
Pierwiastki ziem rzadkich (REE) w wodach powierzchniowych i podziemnych Polski na tle innych krajów Europy
}

\author{
Irena A. Wysocka ${ }^{1}$, Adam Porowski ${ }^{2}$, Anna M. Rogowska ${ }^{1,2}$, Dorota Kaczor-Kurzawa ${ }^{3}$
}

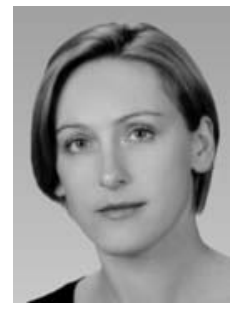

I.A.Wysocka

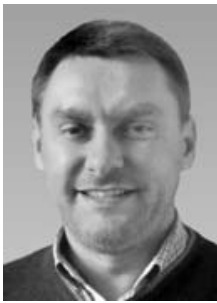

A. Porowski

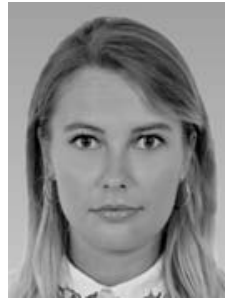

A.M. Rogowska

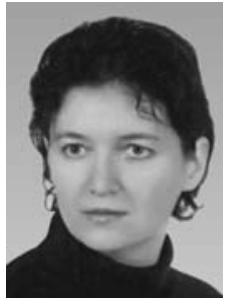

D. Kaczor-Kurzawa

Rare earth elements (REE) in surface and ground waters of Poland in comparison to other European countries. Prz. Geol., 66: 692-705; doi: 10.7306/2018.12

A b s $t r a c t$. This article is focused on the aspects related to the occurrence and the behavior of REE in hydrosphere. Particular attention is given to the natural waters of Europe including Poland. The data shown in this work are based on the studies and discussions published elsewhere, as well as on own investigations of REE concentrations in the natural waters of Poland (ground- and surface waters). The aim of this article is to present information on REE in different types of waters (ocean, ground- and surface waters). Potential sources of REE in the selected waters and factors affecting their concentrations and distribution patterns (signatures) are discussed. The input of REE originating from human activity is indicated and some examples of anthropogenic factors are presented. Additionally, some general information on natural REE abundances in various environmental compartments and their applications in the industry are provided. The potential influence of some major components on determination of europium content in water samples during measurements by mass spectrometry is also explained.

Keywords: rare earth elements, ground waters, surface waters, tap waters, bottled waters, hydrogeology

Lantanowce (Ln) tworzą grupę 15 pierwiastków metalicznych o bardzo zbliżonych właściwościach chemicznych i fizycznych i są tradycyjnie określane wspólną nazwą pierwiastki ziem rzadkich (REE - Rare Earth Elements). Według IUPAC do grupy tej zalicza się również skand (Sc) i itr (Y) ze względu na zbliżone właściwości chemiczne (Connelly i in., 2005). Tak jak wszystkie inne naturalnie występujące na Ziemi pierwiastki są one obecne w różnych elementach środowiska przyrodniczego. Lantanowce wykazują tendencję do wzbogacenia w skorupie ziemskiej - są zatem zaliczane do pierwiastków litofilnych. Pomimo że w skorupie ziemskiej są znacznie rozproszone i nie tworzą typowych złóż w postaci rud metali, to mają bardzo duże znaczenie zarówno gospodarcze, jak i naukowe. Unikalne znaczenie REE w badaniach naukowych wynika z podobieństwa ich właściwości fizycznych i chemicznych, które umożliwiają wykorzystywanie rozkładu ich zawartości w skałach, minerałach czy wodach podziemnych jako wskaźnika wielu ważnych procesów geochemicznych zachodzących w skorupie ziemskiej. Pierwiastki REE są wykorzystywane na szeroką skalę w innowacyjnej gospodarce i zostały zakwalifikowane przez Komisję Europejską jako pierwiastki krytyczne, tzn. niezbędne do rozwoju zaawansowanych technologii. Rozpoznane obecnie użyteczne ekonomicznie zasoby REE są bardzo ograniczone, a stosowane metody ich wydobywania i produkcji uciążliwe dla środowiska, co wymusza rozwój alternatywnych technologii ich poszukiwania i odzysku również ze źródeł niekonwencjonalnych.

Badania naukowe nad zawartością i frakcjonowaniem REE w środowisku skalnym są prowadzone od lat 60. XX w.
Pierwsze prace dotyczyły petrogenezy skał oraz identyfikacji wysokotemperaturowych procesów magmowych z uwzględnieniem zróżnicowania REE pomiędzy roztworami, stopem skalnym i krystalicznymi fazami mineralnymi (Haskin i in., 1968; Schnetzler, Philpots, 1968, 1970; Hanson, 1980). W ostatnich latach łatwiejszy i bardziej powszechny dostęp do czułych technik analitycznych, umożliwiających precyzyjne oznaczenie śladowej zawartości REE $\mathrm{w}$ różnych próbkach środowiskowych oraz $\mathrm{w}$ materiałach odpadowych i antropogenicznych, otworzył nowe perspektywy zastosowania REE w badaniach naukowych i aplikacyjnych.

Pierwiastki ziem rzadkich są obecne także w hydrosferze, zarówno w wodach powierzchniowych, jak i wodach podziemnych. REE przechodzą do wody w wyniku procesów wietrzenia skał lub rekrystalizacji i dehydratacji minerałów, tj. wszelkich procesów oddziaływania w systemie woda-skała. Badania ich zawartości i właściwości geochemicznych W środowisku wodnym upowszechniły się dopiero w latach 80 . XX w. - wraz z rozwojem nowych technik analitycznych, szczególnie spektrometrii mas, pozwalających oznaczać REE z dokładnością do setnych części ng/L. Pierwsze prace dotyczyły występowania i analizy rozkładu stężeń REE w wodach morskich i estuariach (Elderfield, Greaves, 1982; De Baar i in., 1983). Następnie na szerszą skalę zaczęto stosować oznaczenia REE w badaniach hydrologicznych i hydrogeologicznych. Badaniami objęto wody powierzchniowe i podziemne, w tym również wody mineralne i termalne (Michard, Albarede, 1986; De Baar i in., 1988; Goldstein, Jacobsen, 1988; Smedley, 1991; Johannesson i in., 1997a, b, 1999, 2000; Lewis i in.,

\footnotetext{
${ }_{1}^{1}$ Państwowy Instytut Geologiczny - Państwowy Instytut Badawczy, ul. Rakowiecka 4, 00-975 Warszawa; iwys@pgi.gov.pl

${ }^{2}$ Instytut Nauk Geologicznych PAN, ul. Twarda 51/55, 00-818 Warszawa; adamp@twarda.pan.pl

${ }_{3}^{3}$ Państwowy Instytut Geologiczny - Państwowy Instytut Badawczy, Oddział Świętokrzyski, ul. Zgoda 21, 25-953 Kielce; dkac@pgi.gov.pl
} 
1998; Möller, 2002a, b; Möller i in., 2003a, b, 2004, 2008; Tang, Johannesson, 2006; Noack i in., 2014). Obecnie literatura naukowa dotycząca różnych aspektów związanych $\mathrm{z}$ analizą REE $\mathrm{w}$ wodach podziemnych i powierzchniowych jest bardzo bogata. W Polsce zawartość REE jest badana głównie w celu rozpoznania petrogenezy różnych minerałów i skał. Prowadzi się także poszukiwania formacji skalnych o potencjalnie ekonomicznym nagromadzeniu REE (Kubicki, Ryka, 1984; Ryka, 1992; Paulo, 1993; Krzemińska, Krzemiński, 2012). Badania występowania, pochodzenia, stężenia i sygnatury REE (tj. rozkładu REE) w wodach podziemnych, zarówno mineralnych, termalnych, jak i zwykłych, są w Polsce wciąż badaniami pionierskimi (Migaszewski i in., 2014, 2015, 2016; Migaszewski, Gałuszka, 2016; Wysocka, Vassileva, 2017; Rogowska i in., 2018). Wśród publikacji dotyczących REE, których tematyka wykracza poza typowe badania geochemiczne skał, uwzględniając literaturę typu przeglądowego można wymienić prace Kwecko (2016a, b), Mikulskiego i in. (2016) oraz Porowskiego i Kaczor-Kurzawy (2016).

Przedmiotem niniejszego artykułu jest przeglądowe opisanie zawartości REE w różnego rodzaju wodach naturalnych i pitnych na przykładzie danych z krajów europejskich. Na podstawie danych opublikowanych w literaturze naukowej zaprezentowano także stężenia i sygnatury REE w wodach powierzchniowych i podziemnych na terenie Europy. Pokazano przykładowe rozkłady stężenia REE w wodach morskich - początkowej składowej cyklu hydrologicznego. Przedstawiono porównanie stężeń i rozkładów REE w wodach użytkowych o największym znaczeniu dla człowieka - wodach pitnych, zarówno kranowych, jak i butelkowanych. Ponadto przeprowadzono analizę porównawczą rozkładu REE w kontekście wykorzystania sygnatury REE jako wskaźnika pochodzenia wody, wpływu antropopresji na jakość wody i ocenę procesów uzdatniania na zawartość REE w wodach kranowych.

\section{WŁAŚCIWOŚCI CHEMICZNE I FIZYCZNE REE}

Pierwiastki ziem rzadkich (Ln: La-Lu, Sc i Y) mają wiele wspólnych, charakterystycznych cech, które sprawiają, że stanowią one jednorodną grupę metali, użyteczną w badaniach geochemicznych i środowiskowych. REE są najczęściej trójwartościowe. Inne ich wartościowości także są spotykane w przyrodzie, jednak bardzo rzadko - z wyjątkiem ceru (Ce) i europu (Eu), które są czułe na zmiany warunków redoks i mogą występować również jako Ce(IV) i Eu(II) (tab. 1). W środowisku wodnym, w warunkach utle-

Tab. 1. Właściwości chemiczne pierwiastków REE (wg Lide, 2004)

Table 1. Chemical properties of REE (after Lide, 2004)

\begin{tabular}{|c|c|c|c|c|c|c|c|}
\hline $\begin{array}{c}\text { Pierwiastek } \\
\text { Element }\end{array}$ & $\mathbf{Z}$ & $\mathbf{A}_{w}$ & $\mathbf{E}$ & $\begin{array}{c}\mathbf{R}_{\mathrm{a}} \\
{[\mathrm{pm}]}\end{array}$ & $\begin{array}{c}\mathbf{R}_{\mathbf{i}} \\
{[\mathbf{p m}]}\end{array}$ & $\begin{array}{c}\text { EJ } \\
{[\mathrm{eV}]}\end{array}$ & $\begin{array}{c}\text { Konfiguracja elektronowa } \\
\text { Electron configuration }\end{array}$ \\
\hline $\begin{array}{l}\text { Skand (Sc) } \\
\text { Scandium }\end{array}$ & 21 & 44,96 & 3 & 161 & 75 & 6,56 & {$[\mathrm{Ar}] 3 \mathrm{~d}^{1} 4 \mathrm{~s}^{1}$} \\
\hline $\begin{array}{l}\text { Itr }(\mathrm{Y}) \\
\text { Yttrium }\end{array}$ & 39 & 88,91 & 3 & 178 & 102 & 6,22 & {$[\mathrm{Kr}] 4 \mathrm{~d}^{1} 5 \mathrm{~s}^{2}$} \\
\hline $\begin{array}{l}\text { Lantan }(\mathrm{La}) \\
\text { Lanthanum }\end{array}$ & 57 & 138,9 & 3 & 187 & 116 & 5,77 & {$[\mathrm{Xe}] 5 \mathrm{~d}^{1} 6 \mathrm{~s}^{2}$} \\
\hline $\begin{array}{l}\text { Cer }(\mathrm{Ce}) \\
\text { Cerium }\end{array}$ & 58 & 140,1 & $3(4)$ & 183 & 114 & 5,54 & {$[\mathrm{Xe}] 4 \mathrm{f}^{1} 5 \mathrm{~d}^{1} 6 \mathrm{~s}^{2}$} \\
\hline $\begin{array}{l}\text { Prazeodym }(\mathrm{Pr}) \\
\text { Praseodymium }\end{array}$ & 59 & 140,9 & $3(4)$ & 182 & 113 & 5,46 & {$[\mathrm{Xe}] 4 \mathrm{f}^{3} 6 \mathrm{~s}^{2}$} \\
\hline $\begin{array}{l}\text { Neodym }(\mathrm{Nd}) \\
\text { Neodymium }\end{array}$ & 60 & 144,2 & 3 & 181 & 114 & 5,53 & {$[\mathrm{Xe}] 4 \mathrm{f}^{4} 6 \mathrm{~s}^{2}$} \\
\hline $\begin{array}{l}\text { Promet }(\mathrm{Pm}) \\
\text { Promethium }\end{array}$ & 61 & 145 & 3 & 181 & 109 & 5,55 & {$[\mathrm{Xe}] 4 \mathrm{f}^{5} 6 \mathrm{~s}^{2}$} \\
\hline $\begin{array}{l}\text { Samar }(\mathrm{Sm}) \\
\text { Samarium }\end{array}$ & 62 & 150,4 & $3(2)$ & 180 & 108 & 5,64 & {$[\mathrm{Xe}] 4 \mathrm{f}^{6} 6 \mathrm{~s}^{2}$} \\
\hline $\begin{array}{l}\text { Europ (Eu) } \\
\text { Europium }\end{array}$ & 63 & 152 & $3(2)$ & 199 & 107 & 5,67 & {$[\mathrm{Xe}] 4 \mathrm{f}^{7} 6 \mathrm{~s}^{2}$} \\
\hline $\begin{array}{l}\text { Gadolin }(\mathrm{Gd}) \\
\text { Gadolinium }\end{array}$ & 64 & 157,3 & 3 & 179 & 105 & 6,15 & {$[\mathrm{Xe}] 4 \mathrm{f}^{7} 5 \mathrm{~d}^{1} 6 \mathrm{~s}^{2}$} \\
\hline $\begin{array}{l}\text { Terb }(\mathrm{Tb}) \\
\text { Terbium }\end{array}$ & 65 & 158,9 & $3(4)$ & 176 & 118 & 5,86 & {$[\mathrm{Xe}] 4 \mathrm{f}^{9} 6 \mathrm{~s}^{2}$} \\
\hline $\begin{array}{l}\text { Dysproz (Dy) } \\
\text { Dysprosium }\end{array}$ & 66 & 162,5 & 3 & 175 & 103 & 5,94 & {$[\mathrm{Xe}] 4 \mathrm{f}^{10} 6 \mathrm{~s}^{2}$} \\
\hline $\begin{array}{l}\text { Holm }(\mathrm{Ho}) \\
\text { Holmium }\end{array}$ & 67 & 164,9 & 3 & 174 & - & 6,02 & {$[\mathrm{Xe}] 4 \mathrm{f}^{11} 6 \mathrm{~s}^{2}$} \\
\hline $\begin{array}{l}\text { Erb (Er) } \\
\text { Erbium }\end{array}$ & 68 & 167,3 & 3 & 173 & 100 & 6,11 & {$[\mathrm{Xe}] 4 \mathrm{f}^{12} 6 \mathrm{~s}^{2}$} \\
\hline $\begin{array}{l}\text { Tul }(\mathrm{Tm}) \\
\text { Thulium }\end{array}$ & 69 & 168,9 & $3(2)$ & 173 & 109 & 6,18 & {$[\mathrm{Xe}] 4 \mathrm{f}^{13} 6 \mathrm{~s}^{2}$} \\
\hline $\begin{array}{l}\text { Iterb }(\mathrm{Yb}) \\
\text { Ytterbium }\end{array}$ & 70 & 173 & $3(2)$ & 194 & 99 & 6,25 & {$[\mathrm{Xe}] 4 \mathrm{f}^{14} 6 \mathrm{~s}^{2}$} \\
\hline $\begin{array}{l}\text { Lutet }(\mathrm{Lu}) \\
\text { Lutetium }\end{array}$ & 71 & 175 & 3 & 172 & 98 & 5,43 & {$[\mathrm{Xe}] 4 \mathrm{f}^{14} 5 \mathrm{~d}^{1} 6 \mathrm{~s}^{2}$} \\
\hline
\end{tabular}

Objaśnienia: $\mathbf{Z}$ - liczba atomowa, $\mathbf{A}_{w}-$ masa atomowa, $\mathbf{E}$ - wartościowość typowa (rzadko spotykana), $\mathbf{R}_{\mathbf{a}}-$ promień atomowy, $\mathbf{R}_{\mathbf{i}}-$ promień jonowy, $\mathbf{E J}$ - energia jonizacji

Explanations: $\boldsymbol{Z}$-atomic number, $\boldsymbol{A}_{w}$-atomic weight, $\boldsymbol{E}$ - valency: typical (rare), $\boldsymbol{R}_{\boldsymbol{a}}$ - atomic radius, $\boldsymbol{R}_{\boldsymbol{i}}$-ionic radius, $\boldsymbol{E} \boldsymbol{J}$-ionization potential 
niających $\mathrm{Ce}^{3+}$ utlenia się do formy $\mathrm{Ce}^{4+}$, a w warunkach silnie redukcyjnych $\mathrm{Eu}^{3+}$ ulega redukcji do $\mathrm{Eu}^{2+}$. W obu przypadkach dochodzi do zmiany rozmiaru promienia jonowego, co skutkuje różnymi podstawieniami przez jony innych pierwiastków i przyczynia się do wyraźnie widocznej, anomalnej zawartości Ce i Eu w wodzie, w zależności od warunków redoks. Zmiana stopnia utlenienia wpływa również na tworzenie związków chemicznych o różnej rozpuszczalności. Podstawowe właściwości chemiczne REE zestawiono w tabeli 1. W związkach chemicznych REE są silnie elektrododatnie i tworzą wiązania jonowe. Wszystkie lantanowce mają podobne promienie jonowe (promień form $\mathrm{Ln}^{3+}$ wynosi od $98 \mathrm{pm}$ - lutet do $116 \mathrm{pm}$ - lantan), czego konsekwencją jest ich swobodne wzajemne zastępowanie się w różnych strukturach krystalicznych i współwystępowanie w minerałach (tab. 1 i 2). Lantanowce mają również podobną strukturę elektronową, typu $4 \mathrm{f}^{\mathrm{n} 5} \mathrm{~d}^{1} 6 \mathrm{~s}^{2} \mathrm{lub} 4 \mathrm{f}^{\mathrm{n}+1} 6 \mathrm{~s}^{2}$. Ze wzrostem ładunku jądra - od $Z=57(\mathrm{La})$ do $Z=71(\mathrm{Lu})$ - liczba powłok elektronowych nie ulega zmianie, a jedynie zmienia się liczba elektronów walencyjnych. Rośnie więc ich elektrostatyczne przyciaganie przez jądro, co powoduje zmniejszenie się promieni atomowych i jonowych (tzw. kontrakcja lantanowców). Podobieństwo struktury elektronowej w grupie lantanowców odpowiada właśnie za podobieństwo ich właściwości fizycznych i chemicznych.

Pierwiastki REE dzieli się zwykle na trzy grupy (Volker, 2013): lekkie (LREE) - od lantanu $\left({ }^{57} \mathrm{La}\right)$ do europu $\left({ }^{63} \mathrm{Eu}\right)$, średnie (MREE) - od gadolinu $\left({ }^{64} \mathrm{Gd}\right)$ do holmu $\left({ }^{67} \mathrm{Ho}\right)$ oraz ciężkie (HREE) - od erbu $\left({ }^{68} \mathrm{Er}\right)$ do lutetu $\left({ }^{71} \mathrm{Lu}\right)$; do ciężkich zalicza się też itr $\left({ }^{39} \mathrm{Y}\right)$. Lantanowce są bardzo reaktywnymi metalami i w warunkach naturalnych nie występują w czystej postaci elementarnej, lecz jako tlenki lub sole, głównie węglany, fosforany i krzemiany. Pierwiastki te mają wyjątkowe właściwości magnetyczne, optyczne, elektryczne i metalurgiczne. W związku z tym Komisja Europejska zakwalifikowała je do grupy materiałów niezbędnych do rozwoju technologii związanych z produkcją czystej energii oraz zaawansowanych i wysoce precyzyjnych urządzeń (np. monitory LCD, telefony komórkowe, turbiny wiatraków, silniki hybrydowe, elektryczne i indukcyjne, panele słoneczne, pociski samonaprowadzające). REE znalazły również zastosowanie w nowoczesnych technologiach, które są związane z odnawialnymi źródłami energii (OZE). Od lat 70. XX w. utrzymuje się trend stale rosnacego zapotrzebowania na te metale.

\section{WYSTĘPOWANIE W SKORUPIE ZIEMSKIEJ}

Cechy charakterystyczne obecności REE w skorupie ziemskiej to: 1) duże rozproszenie, 2) niewystępowanie w czystej metalicznej postaci, 3) sporadyczne tworzenie minerałów własnych - wyjątek stanowią pegmatyty i hydrotermalne mineralizacje REE związane z karbonatytami (Möller, 2002b). REE nie należą do najrzadziej występujących pierwiastków w skorupie ziemskiej (ryc. 1). Zawartość niektórych lantanowców w skorupie jest podobna do zawartości metali podlegających przemysłowej eksploatacji, takich jak nikiel $(\mathrm{Ni})$, miedź $(\mathrm{Cu})$, chrom $(\mathrm{Cr})$, cynk (Zn), molibden (Mo), cyna (Sn), wolfram (W) lub ołów $(\mathrm{Pb})$. Ilość ceru $(\mathrm{Ce})$ - najbardziej rozpowszechnionego ze wszystkich REE - jest większa niż miedzi $(\mathrm{Cu}) \mathrm{czy}$ ołowiu $(\mathrm{Pb})$. Do najrzadszych lantanowców są zaliczane tul (Tm) i lutet (Lu), których jest w skorupie ziemskiej ok. 100 razy mniej od ceru, ale i tak są one ok. 200 razy bardziej rozpowszechnione niż złoto (Lide, 2004; Haxel i in., 2002).

Pomimo podobnych właściwości geochemicznych REE, ich zawartość w skałach jest bardzo zróżnicowana i uzależniona od typu skały i jej pochodzenia; zwykle wynosi od 0,1 do $100 \mathrm{mg} / \mathrm{kg}$ (ryc. 1). Zawartość poszczególnych pierwiastków ziem rzadkich w kontynentalnej skorupie ziemskiej, w złożach REE i pierwotnych fazach mineralnych może się różnić od dwóch do pięciu rzędów wielkości. Jest to spowodowane dwoma czynnikami (Aide, Aide, 2012): 1) budową atomów - REE z parzystą liczbą atomową (np. ${ }^{58} \mathrm{Ce},{ }^{60} \mathrm{Nd}$ ) są bardziej rozpowszechnione na Ziemi niż te $\mathrm{z}$ nieparzystą liczbą atomową (np. $\left.{ }^{57} \mathrm{La},{ }^{59} \mathrm{Pm}\right)$; 2) właściwościami geochemicznymi - lżejsze REE (LREE) mają większy promień atomowy, przez to są rzadziej podstawiane innymi pierwiastkami i wykazują większą tendencję do koncentracji $\mathrm{w}$ fazach mineralnych niż cięższe REE (HREE).

W większości złóż REE cztery pierwsze pierwiastki $\mathrm{La}, \mathrm{Ce}, \mathrm{Pr}, \mathrm{Nd}$ - stanowią w nich aż 80-90\%. Granity i riolity zawierają więcej REE niż bazalty i perydotyty. Natomiast łupki i utwory gliniaste charakteryzują się zwykle większą koncentracją REE w porównaniu do wapieni i piaskowców. Zarówno w utworach magmowych, jak i osadowych obserwuje się większą zawartość LREE niż HREE. Dotychczas rozpoznano ponad 250 minerałów, w których występują REE, ale tylko ok. $12 \mathrm{z}$ nich ma znaczenie przemysłowe ze względu na zawartość tlenków metali ziem rzadkich (tab. 2). Ponadto podobne właściwości chemiczne i fizyczne REE sprawiają, że ich wydzielanie z rudy jest trudne technologicznie.

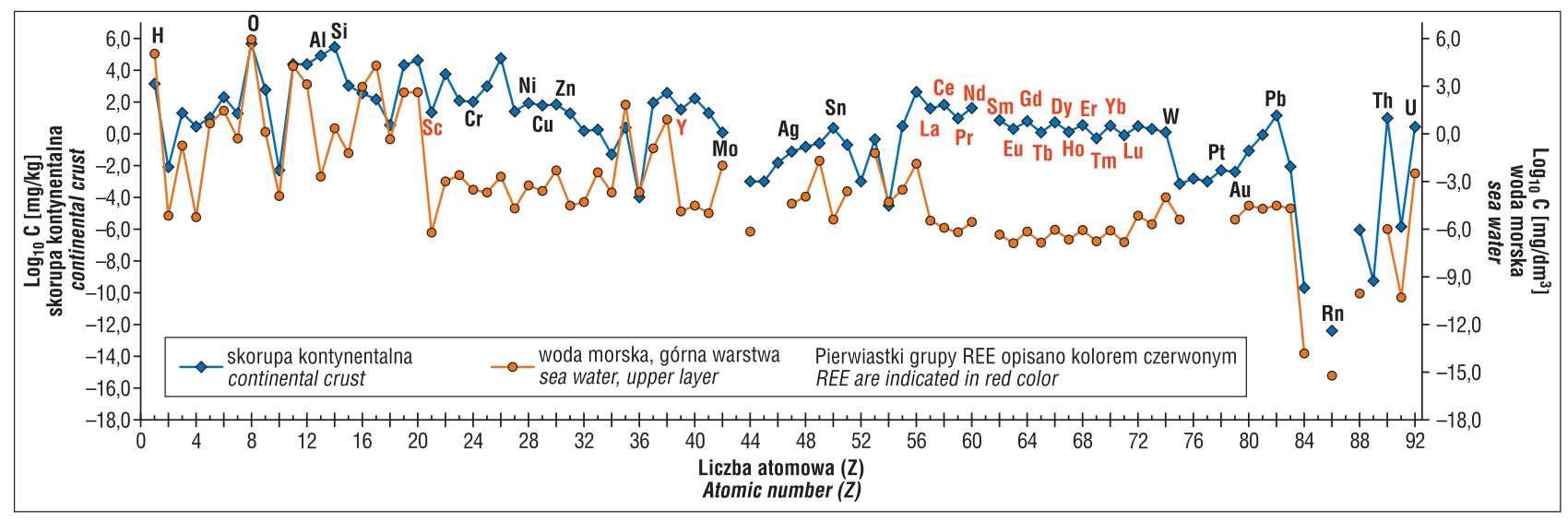

Ryc. 1. Średnia zawartość pierwiastków w skorupie kontynentalnej Ziemi i w górnej warstwie wód morskich (dane wg Lide, 2004)

Fig. 1. Average estimated abundance of elements in the Earth's crust and sea water (upper layer) for comparison (data after Lide, 2004) 
Tab. 2. Główne minerały zawierające REE uznawane za surowce mineralne (Zhang, Zhao, 2016)

Table 2. Main REE minerals occuring in the Earth's crust as economic deposits (Zhang, Zhao, 2016)

\begin{tabular}{|l|c|c|}
\hline \multicolumn{1}{|c|}{$\begin{array}{c}\text { Mineral } \\
\text { Mineral }\end{array}$} & $\begin{array}{c}\text { Wzór chemiczny } \\
\text { Chemical formula }\end{array}$ & $\begin{array}{c}\text { Zawartość tlenków } \\
\text { pierwiastków ziem rzadkich - REO [\%] } \\
\text { REE oxide content [\%] }\end{array}$ \\
\hline Bastnäsyt / Bastnäsite & $(\mathrm{Ln})\left[\mathrm{F} \mid \mathrm{CO}_{3}\right]$ & 74,8 \\
\hline Monacyt / Monazite & $\left(\mathrm{Ln}, \mathrm{Th}^{2}\right)\left[\mathrm{PO}_{4}\right]$ & 65,1 \\
\hline Ksenotym / Xenotime & $\mathrm{Y}\left[\mathrm{PO}_{4}\right]$ & 62 \\
\hline Fluoceryt / Fluocerite & $(\mathrm{Ce}, \mathrm{La}, \ldots) \mathrm{F}_{3}$ & 83,4 \\
\hline Parisyt / Parisite & $(\mathrm{Ln})_{2} \mathrm{Ca}\left[\mathrm{F}_{2} \mid\left(\mathrm{CO}_{3}\right)_{2}\right]$ & 60,3 \\
\hline Fergusonit / Fergusonite & $\mathrm{YNbO}_{4}$ & 39,9 \\
\hline Gadolinit / Gadolinite & $\mathrm{Y}{ }_{2} \mathrm{Fe}{ }_{2}+\mathrm{Be}_{2}\left[\mathrm{O} \mid \mathrm{SiO}_{4}\right]_{2}$ & 48,3 \\
\hline Aeshynit / Aeschynite & $(\mathrm{Y}, \ldots)(\mathrm{Nb}, \mathrm{Ti})_{2}(\mathrm{O}, \mathrm{OH})_{6}$ & 24,6 \\
\hline Euksenit / Euxenite & $(\mathrm{Y}, \mathrm{Ce}, \mathrm{U}, \mathrm{Pb}, \mathrm{Ca})(\mathrm{Nb}, \mathrm{Ta}, \mathrm{Ti})_{2}(\mathrm{O}, \mathrm{OH})_{6}$ & 24,3 \\
\hline Synchisit / Synchysite & $\mathrm{Ca}(\mathrm{Ce}, \mathrm{La})\left[\mathrm{F} \mid(\mathrm{CO})_{2}\right]$ & 49,6 \\
\hline Samarskit / Samarskite & $\left(\mathrm{Y}, \mathrm{U}, \mathrm{Fe}{ }^{3+}\right)(\mathrm{Nb}, \mathrm{Ta}) \mathrm{O}_{4}$ & 24,3 \\
\hline Polikraz / Polycrase & $(\mathrm{Y}, \mathrm{Ce}, \mathrm{Ca}, \mathrm{U}, \mathrm{Th})(\mathrm{Ti}, \mathrm{Nb}, \mathrm{Ta})_{2}(\mathrm{O}, \mathrm{OH})_{6}$ & 19,5 \\
\hline Loparyt / Loparite & $(\mathrm{Ce}, \mathrm{Ca}, \mathrm{Na})(\mathrm{Ti}, \mathrm{Nb}) \mathrm{O}_{3}$ & 29,8 \\
\hline
\end{tabular}

Objaśnienia: Ln - oznacza grupę lantanowców (La-Lu), REO - tlenki pierwiastków ziem rzadkich

Explanations: $\mathbf{L} \boldsymbol{n}$ - lanthanides group ( $L a-L u), \boldsymbol{R E} \boldsymbol{O}$ - Rare Earth Oxides

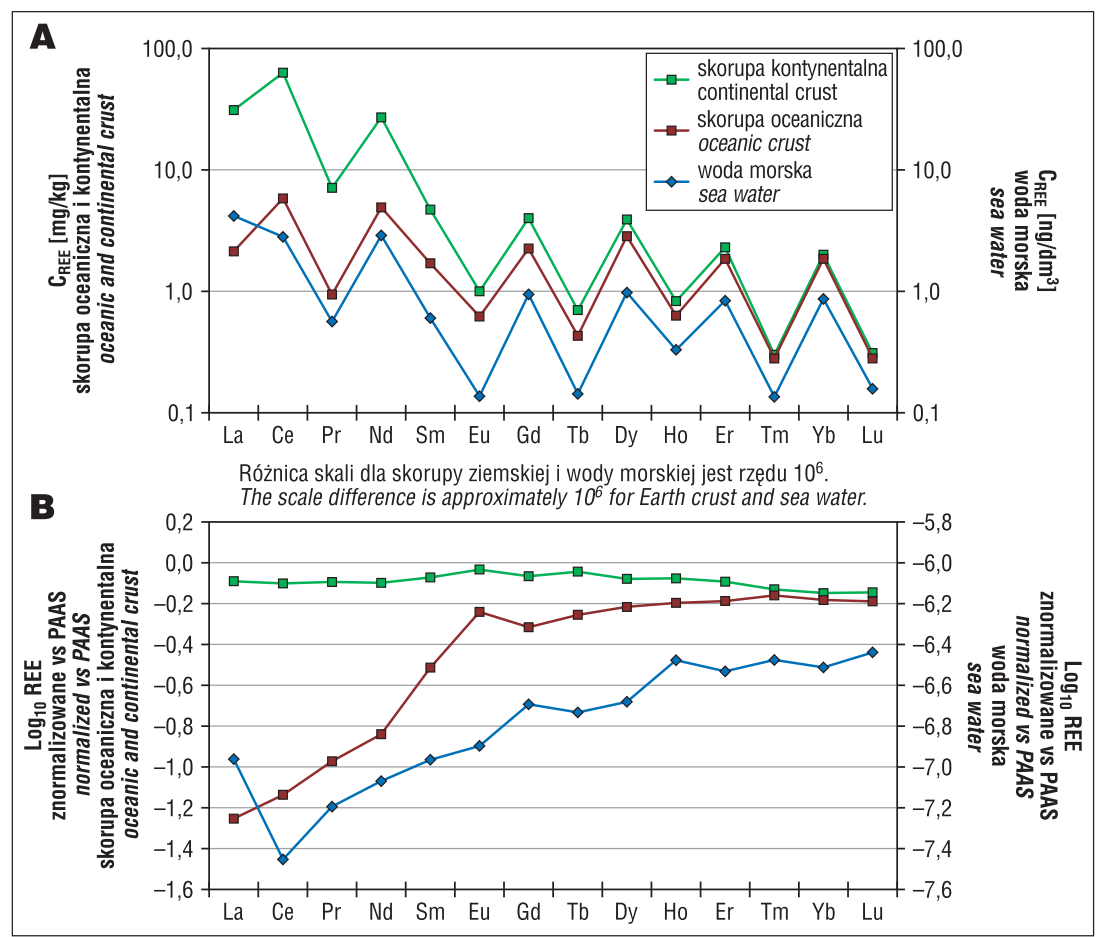

\section{$\leftarrow$}

Ryc. 2. Porównanie rozkładu nieznormalizowanej zawartości REE w skorupie ziemskiej i wodzie oceanicznej (A) oraz po znormalizowaniu względem wzorca PAAS (B). Różnica skali dla skorupy ziemskiej i wody morskiej jest rzędu $10^{6}$ (dane wg Lide, 2004; Hoshino i in., 2016)

Fig. 2. Comparison between REE concentration in Earth crust and sea water (A) and REE-pattern normalized vs PAAS (B). The scale difference is approximately $10^{6}$ for Earth crust and sea water (data after Lide, 2004; Hoshino et al., 2016)

skorupie oceanicznej i wodzie morskiej po znormalizowaniu $\mathrm{w}$ stosunku do wzorca PAAS i bez normalizacji. Znormalizowany względem wzorca PAAS rozkład zawartości REE w skorupie oceanicznej i wodzie morskiej wykazuje wyraźne zubożenie w LREE w stosunku do skały wzorcowej, przy czym stężenia REE w wodzie morskiej są ok. milion

Różnego rodzaju analizy porównawcze rozkładu zawartości REE w skałach lub wodach są dokonywane na podstawie analizy ich koncentracji w skałach przyjętych jako geologiczne materiały odniesienia (wzorce) - tj. reprezentujących pierwotną zawartość REE w momencie formowania się skał skorupy ziemskiej, a więc bez wpływu procesów wtórnych. Najczęściej normalizacji dokonuje się względem zawartości REE w chondrycie (np. chondryt C1) lub skałach łupkowych (np. ang. PAAS - Post Archean Australian Shale). Normalizacja ma za zadanie wyeliminowanie różnicy zawartości REE wynikającej z budowy atomów, tj. parzystej i nieparzystej liczby atomowej kolejnych pierwiastków. Dla przykładu na rysunku 2 przedstawiono porównanie zawartości REE w skorupie kontynentalnej, razy mniejsze niż w skorupie kontynentalnej i oceanicznej. Horyzontalny rozkład znormalizowanej zawartości REE w skorupie kontynentalnej jest bliski wartości zero i świadczy o braku zubożenia lub wzbogacenia w stosunku do PAAS (ryc. 2).

\section{WYSTEPOWANIE REE W WODACH POWIERZCHNIOWYCH I PODZIEMNYCH}

W wyniku takich procesów, jak wietrzenie czy diageneza, pierwiastki ziem rzadkich są dość łatwo uruchamiane i przenoszone ze środowiska skalnego do wody. Zawartość REE we wszystkich rodzajach wód, od wód morskich po wody podziemne i powierzchniowe, jest kilka rzędów 
wielkości mniejsza niż w skałach. W przypadku węglanów różnica $w$ koncentracji REE pomiędzy skałą a wodą może wynosić od $10^{2}$ do $10^{6}$ (McLennan, 1989). Związki chemiczne lantanowców (zarówno tlenki, wodorotlenki, węglany, fluorki, fosforany, jak i szczawiany) są bardzo słabo rozpuszczalne $\mathrm{w}$ wodzie, a ich rozpuszczalność nieznacznie maleje wraz ze zmniejszaniem się promienia jonowego. $\mathrm{W}$ zależności od $\mathrm{pH}$, temperatury, warunków redoks, procesów mikrobiologicznych oraz zawartości substancji rozpuszczonych w wodzie (jonów organicznych i nieorganicznych, gazów) procesy chemicznego wietrzenia i ługowania skał przebiegają w różny sposób, co powoduje, że REE zawarte $w$ minerałach przechodzą do środowiska wodnego w określonych ilościach. W wodach podziemnych i powierzchniowych niezanieczyszczonych antropogenicznie zawartość pierwiastków ziem rzadkich zwykle znajduje się na poziomie ng/L. Podwyższone stężenia REE świadczą zwykle o rozpuszczaniu minerałów akcesorycznych wzbogaconych w REE (Mclennan, 1989).

\section{REE W WODZIE MORSKIEJ}

Wody mórz i oceanów stanowią 97,2\% objętości całej wody w hydrosferze i można je uznać za drugi co do wielkości rezerwuar REE na Ziemi. Głównym źródłem pierwiastków REE w wodzie morskiej jest wietrzenie skorupy kontynentalnej. Spływ powierzchniowy i transport eoliczny to główne drogi, którymi lantanowce przedostają się do wody morskiej. REE są transportowane do mórz i oceanów wraz z dopływającymi wodami rzecznymi (w mniejszym stopniu w wyniku bezpośredniej infiltracji wód podziemnych) w formie różnych związków chemicznych rozpuszczonych i zawieszonych w wodzie oraz w formie drobnych cząstek i minerałów zawieszonych w powietrzu i nawiewanych od strony lądów. Średnie stężenie REE w wodzie morskiej jest mniejsze niż w wodach powierzchniowych i podziemnych, a także milion razy mniejsze niż w skorupie ziemskiej. Typowe stężenie REE w wodzie morskiej waha się od dziesiętnych części ng/L - np. Lu i Tm - do ok. kilku lub nawet kilkunastu ng/L-np. La i Nd (ryc. 2 i 3 ).

W otwartych akwenach mórz i oceanów w przypowierzchniowej warstwie wody z dala od brzegów typowa sygnatura REE wykazuje zubożenie w LREE i stopniowe wzbogacenie w HREE oraz wyraźnie widoczną, charak- terystyczną, ujemną anomalię Ce. W strefach przybrzeżnych, w ujściach dużych rzek, w estuariach i w strefach mieszania się wód powierzchniowych czy podziemnych z wodą morską zawartość REE jest wyraźnie większa niż w wodzie morskiej z dala od brzegu (ryc. 3). Sygnatura REE dla wód morskich w takich strefach mieszania wykazuje również zupełnie inny profil: jest on wyraźnie spłaszczony i w przybliżeniu $\mathrm{La}_{\mathrm{N}} \approx \mathrm{Ce}_{\mathrm{N}} \approx \operatorname{Pr}_{\mathrm{N}} \approx \mathrm{Lu}_{\mathrm{N}}$. W ostatnich latach obserwuje się wyraźną dodatnią anomalię Gd (Hatje i in., 2016), która jest wskaźnikiem udziału wód zanieczyszczonych antropogenicznie, dopływających rzekami z lądu (ryc. 3). Zróżnicowanie rozkładu zawartości REE wynika z tego, że w strefie mieszania się wód na granicach mniejszego i większego zasolenia następuje szybkie usuwanie lantanowców z wody (tj. ich formy rozpuszczonej, występującej najczęściej w postaci kompleksów węglanowych) w wyniku indukowanych wysokim zasoleniem procesów koagulacji, flokulacji i adsorpcji REE na cząstkach koloidalnych, głównie organicznych, bogatych w Fe czy Mn, które następnie opadają w kierunku dna (Deng i in., 2017). W pierwszej kolejności są usuwane LREE. Wszystkie czynniki i procesy kształtujące obieg i rozkład zawartości REE w wodach mórz i oceanów nie zostały jeszcze do końca poznane. Na podstawie wyników wielu badań stwierdzono, że stężenie REE w wodach Oceanu Spokojnego i Atlantyckiego wzrasta wraz z głębokością (Alibo, Nozaki, 1999). Na rycinie 4 przedstawiono zmienność stężenia REE w wodzie Oceanu Spokojnego w przekroju pionowym. W wodach Oceanu Atlantyckiego średnie stężenia REE są mniejsze niż w Oceanie Spokojnym. Inaczej zachowują się lantanowce w wodach Oceanu Arktycznego, w którym stwierdzono większą zawartość REE w strefie wody powierzchniowej niż w strefie wody głębokiej, poniżej $500 \mathrm{~m}$ (Deng i in., 2017; Yang, Haley, 2016). W wodzie na głębokości 200-500 m stężenie REE w Oceanie Arktycznym nie różni się od stężenia REE w Oceanie Atlantyckim i Spokojnym.

Wzrost zawartości REE w wodzie morskiej wraz z głębokością może być spowodowany wieloma czynnikami. Do najważniejszych z nich można zaliczyć: 1) procesy biogeochemiczne - głównie związane z asymilacją związków chemicznych (azotany, siarczany, fosforany) przez fitoplankton w płytszych strefach i remineralizacją w głębszych strefach minimum tlenowego; 2) rozpuszczanie cząstek

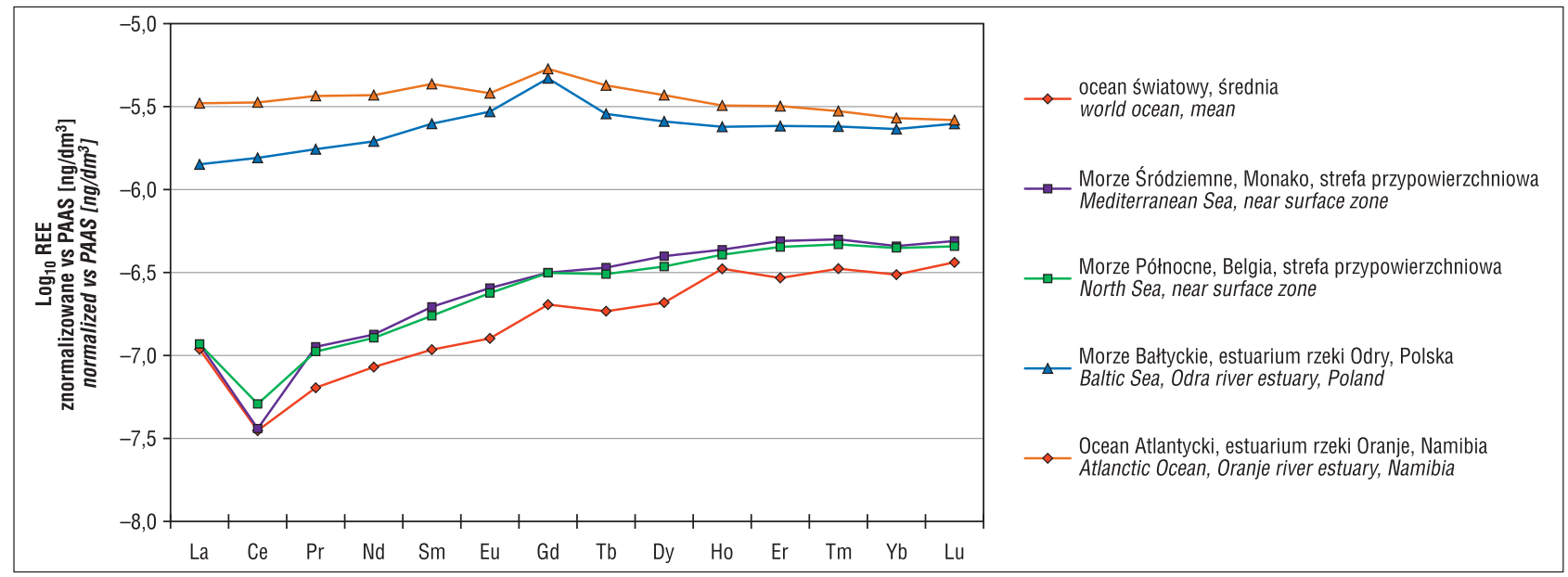

Ryc. 3. Znormalizowany w stosunku do PAAS rozkład zawartości pierwiastków ziem rzadkich w wodach oceanu światowego (średnia zawartość REE, dane wg Lide, 2004) oraz innych wodach morskich (Wysocka, Vassileva, 2017)

Fig. 3. Comparison of PAAS-normalized REE concentration patterns for average world ocean water (data after Lide, 2004) and sea water from different locations (Wysocka, Vassileva, 2017) 


\section{$\longrightarrow$}

Ryc. 4. Stężenie REE rozpuszczonych w wodach Oceanu Spokojnego w zależności od głębokości (dane wg Alibo, Nozaki, 1999)

Fig. 4. Depth profiles of dissolved concentration of REE in the Pacific Ocean waters (data after Alibo, Nozaki, 1999)

koloidalnych bogatych w lantanowce zaadsorbowane w głębszych strefach mórz i oceanów; 3) dopływ wód porowych bogatych w REE $\mathrm{z}$ osadów dennych (Piepgras, Jacobsen, 1992; Alibo, Nozaki, 1999; Schijf i in., 2015; Deng i in., 2017). Cyrkulacja wód w oceanach jest najważniejszym czynnikiem odpowiedzialnym za rozkład zawartości REE w wodach morskich na Ziemi. Jednakże wody tworzą w oceanach poziome warstwy, różniące się od siebie temperaturą i zasoleniem, i prawie nie mieszają się ze sobą. Dopóki nie zmieni się temperatura lub zasolenie wody, może się ona przemieszczać tylko w poziomie.

\section{REE W WODACH POWIERZCHNIOWYCH}

Zawartość lantanowców w wodach powierzchniowych (rzekach i strumieniach) jest znacznie bardziej zróżnicowana niż w wodach morskich. W poszczególnych rodzajach wód różnice w koncentracji REE mogą przekraczać nawet 10 rzędów wielkości, przy czym typowy zakres zmienności mieści się w przedziale od 2 do 4 rzędów wielkości (Noack i in., 2014). W tabeli 3 zestawiono wyniki pomiarów stężenia REE w wodach powierzchniowych Europy, obejmujące 26 krajów, w tym Polskę. Dane pochodzą z Atlasu geochemicznego Europy, realizowanego pod auspicjami Forum Europejskich Służb Geologicznych (FOREGS), wydanego w 2005 r. (Salminen i in., 2005). Atlas zawiera informacje dotyczące tła geochemicznego

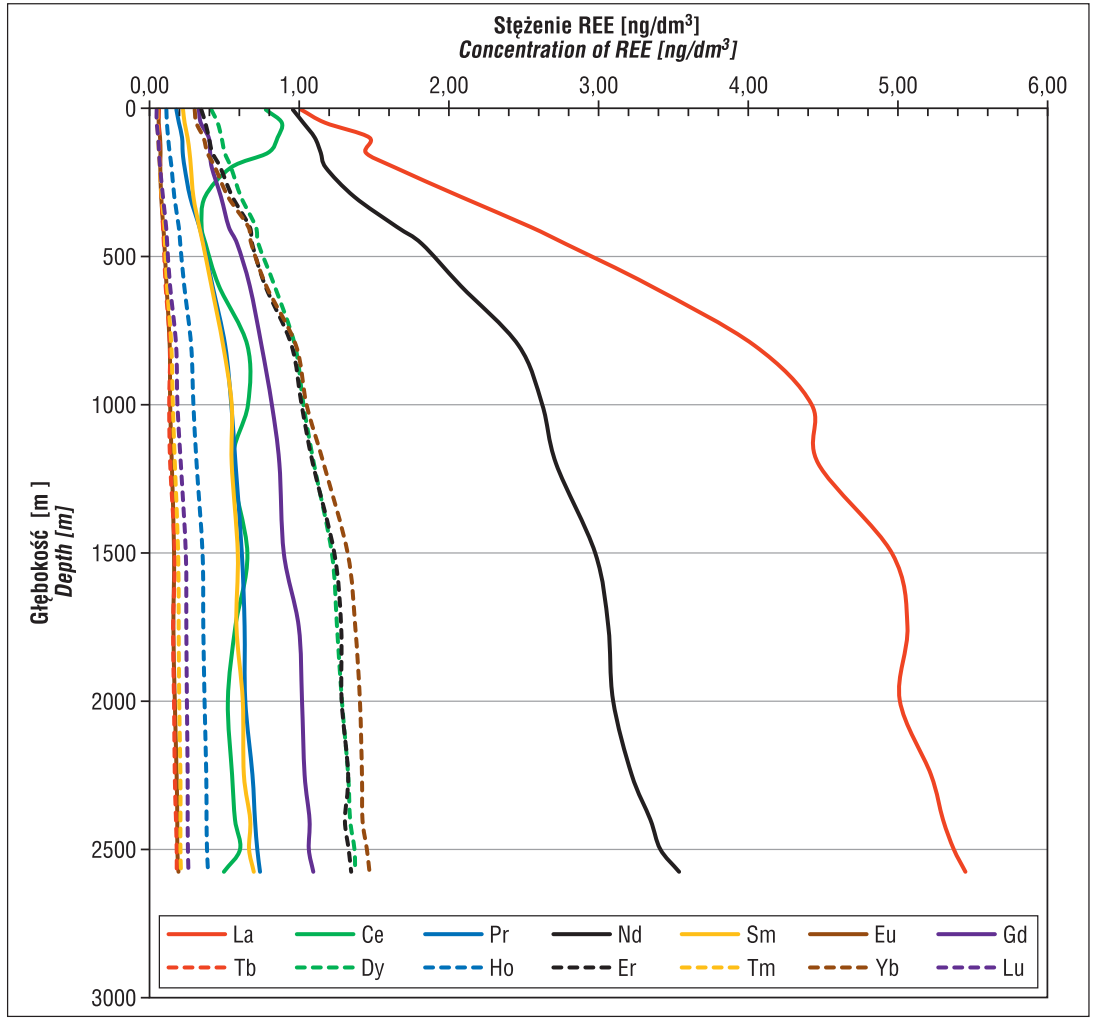

ponad 50 pierwiastków, w tym REE, w różnych próbkach środowiskowych, tj. wodach cieków powierzchniowych (badaniami objęto przede wszystkim niewielkie cieki i strumienie wyższych rzędów), w osadach strumieniowych i tarasów zalewowych oraz w glebach. Próbki wód powierzchniowych pobrano z ok. 800 punktów na terenie Europy. Każdy z nich reprezentował ok. $100 \mathrm{~km}^{2}$ powierzchni zlewni, co dało w przybliżeniu średnią gęstość opróbowania równą 1 próbce wody na $4700 \mathrm{~km}^{2}$. Ponieważ zastosowano jednolite metody opróbowania, analiz chemicznych wszystkich próbek i statystycznego opracowania danych, uzyskane wyniki mogą być traktowane jako wartości referencyjne do porównywania danych geochemicznych z poszczególnych regionów (np. państw).

Wyniki badań zawartości REE, analizy statystyczne i mapy geochemiczne opublikowane w Atlasie geochemicznym

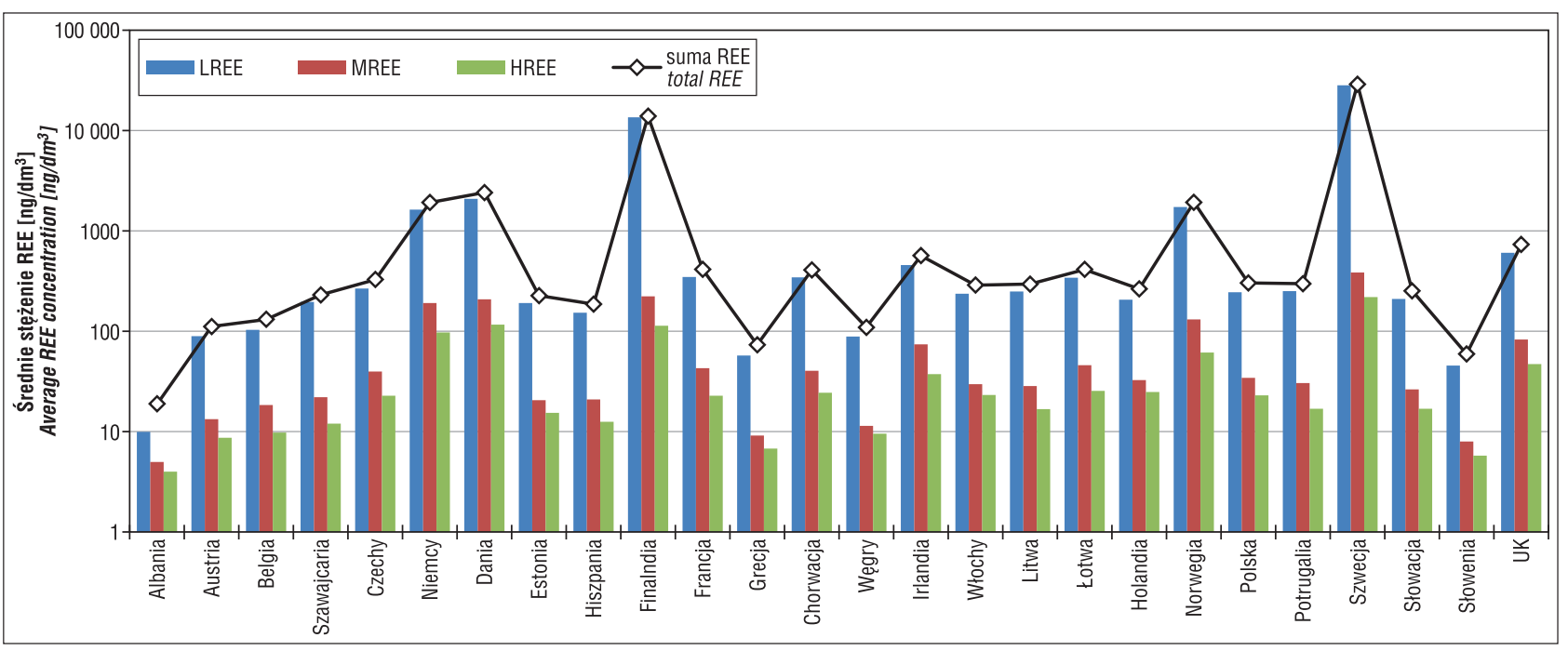

Ryc. 5. Średnie stężenie REE w wodach powierzchniowych państw europejskich (dane wg Salminen i in., 2005)

Fig. 5. Average REE concentration in surface water of European countries (data after Salminen et al., 2005) 
Europy (Salminen i in., 2005) potwierdzają, że przestrzenny rozkład i zawartość REE w wodach powierzchniowych zależą głównie od budowy geologicznej danego obszaru. Zróżnicowanie stężeń REE w wodach odzwierciedla układ prowincji tektonicznych, typy geochemiczne dużych jednostek litologicznych, zasięg ostatniego zlodowacenia oraz emisji zanieczyszczeń pochodzących z obszarów intensywnej działalności człowieka (antropopresja przemysłowa, rolnicza itp.). Na rycinie 5 przedstawiono średnie stężenie REE $w$ wodach powierzchniowych państw europejskich.
Analizowane wody powierzchniowe Europy charakteryzowały się: 1) niską mineralizacją ogólną - ok. 94\% spośród wszystkich badanych wód miało przewodnictwo właściwe poniżej $1000 \mu \mathrm{S} / \mathrm{cm}$, a średnia wartość EC wynosiła $447,5 \mu \mathrm{S} / \mathrm{cm}$; 2) obojętnym pH i 3) podwyższoną ilością rozpuszczonej materii organicznej (Salminen i in., 2005). Prowadzone od ok. czterech dekad intensywne badania, mające na celu poznanie zachowania się REE w wodach powierzchniowych, wskazują, że ich zawartość w wodach rzecznych jest kontrolowana głównie przez dwa czynniki, mianowicie przez zawartość materii organicznej i pH wody.

Tab. 3. Występowanie REE w wodach powierzchniowych Europy i Polski. Dane statystyczne obejmują 807 punktów pomiarowych zlokalizowanych w 26 krajach Europy wraz z Polską (Salminen i in., 2005)

Tab. 3. REE concentrations for surface stream waters in Europe and Poland. Statistical data derived from 807 stations localized in 26 European countries including Poland (Salminen et al., 2005)

\begin{tabular}{|c|c|c|c|c|c|c|c|c|}
\hline \multirow{2}{*}{$\begin{array}{l}\text { Parametr } \\
\text { Parameter }\end{array}$} & \multicolumn{4}{|c|}{$\begin{array}{l}\text { Wody powierzchniowe Europy } \\
\text { Surface waters in Europe }\end{array}$} & \multicolumn{4}{|c|}{$\begin{array}{l}\text { Wody powierzchniowe Polski } \\
\text { Surface waters in Poland }\end{array}$} \\
\hline & $\begin{array}{c}\text { średnia } \\
\text { mean }\end{array}$ & $\begin{array}{c}\text { mediana } \\
\text { median }\end{array}$ & $\begin{array}{l}\text { minimum } \\
\text { minimum }\end{array}$ & $\begin{array}{c}\text { maksimum } \\
\text { maximum }\end{array}$ & $\begin{array}{c}\text { średnia } \\
\text { mean }\end{array}$ & $\begin{array}{c}\text { mediana } \\
\text { median }\end{array}$ & $\begin{array}{l}\text { minimum } \\
\text { minimum }\end{array}$ & $\begin{array}{c}\text { maksimum } \\
\text { maximum }\end{array}$ \\
\hline $\mathrm{pH}$ & 7,5 & 7,7 & 2,2 & 9,8 & 7,7 & 7,7 & 6,7 & 9,1 \\
\hline $\mathrm{EC}[\mu \mathrm{S} / \mathrm{cm}]$ & 447,5 & 300 & 5 & 17100 & 432,8 & 398 & 133 & 1040 \\
\hline $\mathrm{DOC}[\mathrm{mg} / \mathrm{L}]$ & 7,76 & 4,99 & $<0,5$ & 71,9 & b.d. & b.d. & b.d. & b.d. \\
\hline 1. próbek / n. of samples & \multicolumn{4}{|c|}{$\mathrm{n}=807$} & \multicolumn{4}{|c|}{$\mathrm{n}=56$} \\
\hline REE & \multicolumn{4}{|c|}{$[\mathrm{ng} / \mathrm{L}]$} & \multicolumn{4}{|c|}{$[\mathrm{ng} / \mathrm{L}]$} \\
\hline $\mathrm{La}$ & 220,84 & 34 & 1 & 16000 & 50,41 & 22 & 3 & 340 \\
\hline $\mathrm{Ce}$ & 400,11 & 55 & 1 & 36000 & 99,38 & 38 & 4 & 820 \\
\hline $\operatorname{Pr}$ & 57,18 & 9 & 1 & 4700 & 14,02 & 6 & 1 & 100 \\
\hline $\mathrm{Nd}$ & 227,37 & 40 & 1 & 19800 & 61,8 & 27 & 2 & 450 \\
\hline $\mathrm{Sm}$ & 44,07 & 9 & 1 & 3820 & 14,7 & 7 & 1 & 100 \\
\hline $\mathrm{Eu}$ & 10,12 & 4,7 & 1 & 870 & 6,09 & 4 & 2 & 30 \\
\hline Gd & 45,29 & 10 & 1 & 4320 & 14,82 & 8 & 1 & 120 \\
\hline $\mathrm{Tb}$ & 6,56 & 2 & 1 & 590 & 2,39 & 1 & 1 & 18 \\
\hline Dy & 35,88 & 8 & 1 & 3430 & 14 & 7,5 & 1 & 130 \\
\hline Ho & 7,69 & 2 & 1 & 710 & 3,09 & 2 & 1 & 29 \\
\hline $\mathrm{Er}$ & 22,65 & 6 & 1 & 2080 & 9,75 & 6 & 1 & 90 \\
\hline $\mathrm{Tm}$ & 3,62 & 1 & 1 & 280 & 1,79 & 1 & 1 & 13 \\
\hline $\mathrm{Yb}$ & 21,58 & 5,7 & 1 & 1790 & 9,54 & 5 & 1 & 90 \\
\hline $\mathrm{Lu}$ & 4 & 1 & 1 & 300 & 1,91 & 1 & 1 & 16 \\
\hline Y & 247,1 & 64 & 3 & 26600 & 103,68 & 63 & 7 & 910 \\
\hline
\end{tabular}

b.d. - brak danych / no data

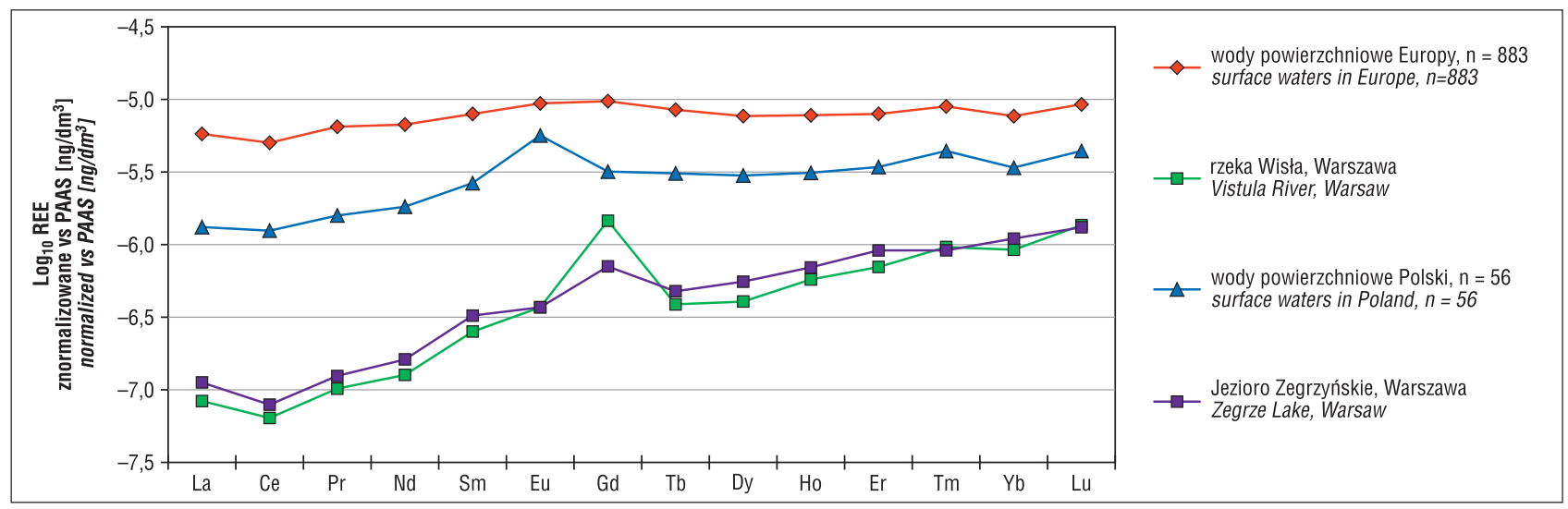

Ryc. 6. Znormalizowany rozkład REE w wodach powierzchniowych Europy i Polski (dane wg Salminen i in., 2005; Rogowska i in., 2018) Fig. 6. PAAS-normalized REE concentration patterns for surface waters in Europe and Poland (data a. Salminen et al., 2005; Rogowska et al., 2018) 
Materia organiczna (cząstki zawieszone oraz substancja koloidalna), na której adsorbują się znaczne ilości REE, jest zwykle wzbogacona w LREE i MREE - tym samym woda jest zubożona w rozpuszczone LREE i MREE (ryc. 6). Na zmniejszenie ogólnej zawartości REE w wodzie wpływa również wzrost $\mathrm{pH}$ wody. Znormalizowane stężenia REE w wodach powierzchniowych przedstawiono na rycinie 6 .

W wodach o pH zbliżonym do obojętnego REE występują przeważnie jako uwodnione wolne jony $\left(\mathrm{Ln}^{3+}\right)$, a formy kompleksowe (głównie $\mathrm{z}$ anionami węglanowymi, fluorkowymi, siarczanowymi i hydroksylowymi) stanowia niewielką ich frakcję. W wodach alkalicznych, w których ciśnienie cząstkowe $\mathrm{CO}_{2}$ jest większe lub równe atmosferycznemu, związki kompleksowe REE są zdominowane przez kompleksy węglanowe $\mathrm{LnCO}^{3+} \mathrm{i} \mathrm{Ln}\left(\mathrm{CO}_{3}\right)^{2-}$ (Luo, Byrne, 2004). W zaprezentowanym przez Tanga i Johannesson (2003) modelu specjacyjnym, zastosowanym do tzw. średniej wody rzecznej ( $\mathrm{pH} \sim 5-8$ ), założono, że w większości wód rzecznych drenujących kontynenty przeważają kompleksy $\mathrm{z}$ materią organiczną. Natomiast $\mathrm{w}$ środowisku kwaśnym dominują wolne jony metali i kompleksy siarczanowe. Stężenia poszczególnych REE w rzekach nie przekraczają zwykle $1 \mu \mathrm{g} / \mathrm{L}$ (Neal, Robson, 2000). Znormalizowany rozkład względem PAAS, otrzymany dla średniej zawartości REE we wszystkich analizowanych wodach powierzchniowych na terenie Europy, nie wykazuje znacznego zróżnicowania pomiędzy LREE i HREE (ryc. 6). Natomiast w wodach Polski jest zauważalne nieznaczne zróżnicowanie, ponadto jest widoczna dodatnia anomalia Eu. W wodach dużych rzek, przepływających przez znaczne obszary i niosących różną ilość zanieczyszczeń antropogenicznych, charakterystyczną cechą jest wyraźnie zaznaczająca się dodatnia anomalia Gd (Bau, Dulski, 1996; Migaszewski, Gałuszka, 2016; Hatje i in., 2016), która została zaobserwowana także w wodach Wisły (ryc. 6) i w mniejszym stopniu Jeziora Zegrzyńskiego (Rogowska i in., 2018).

\section{REE W WODACH PODZIEMNYCH}

Stężenia i sygnatury REE w wodach podziemnych zależą głównie od litologii i składu mineralnego skał, z którymi wody te mają kontakt w warstwie wodonośnej. Ponadto można wyróżnić kilka innych istotnych czynników mających wpływ na stężenia REE w wodach: 1) obecność procesów rozpuszczania i wytrącania faz mineralnych, 2) $\mathrm{pH}$, temperatura i warunki redoks panujące w warstwie wodonośnej, 3) procesy adsorpcji, 4) obecność jonów kompleksujących REE, 5) warunki hydrogeologiczne, np. drogi krążenia wód, czas występowania w warstwie wodonośnej, pochodzenie wody. Ważnym czynnikiem warunkującym stężenia i sygnaturę REE w wodach podziemnych, niezależnie od ich temperatury, jest $\mathrm{pH}$. Obniżenie $\mathrm{pH}$ powoduje wzrost reaktywności wody w stosunku do skał i w konsekwencji wzrost stężenia REE w wodzie. Ma to znaczenie w zastosowaniu sygnatury REE do identyfikacji stref zasilania wód podziemnych. W obszarach infiltracji $\mathrm{pH}$ wody jest na ogół niższe, co sprawia, że wzbogaca się ona w REE na kontakcie z utworami skalnymi zawierającymi te pierwiastki. Zawartość lantanowców w wodach podziemnych, podobnie jak w innych rodzajach wód, jest znacznie mniejsza niż w skałach, a różnice sięgają od kilku do nawet kilkunastu rzędów wielkości. Podobnie jak w wodach powierzchniowych, stężenia REE w wodach podziemnych mogą być bardzo zróżnicowane, a różnice koncentracji mogą przewyższać nawet 4 rzędy wielkości, w zależności od rodzaju wód podziemnych, ich chemizmu, pochodzenia oraz czasu występowania w warstwie wodonośnej (Reimann, Birke, 2010).

Literatura dotycząca różnych aspektów związanych z występowaniem REE w wodach podziemnych jest bardzo bogata. W celu porównania występowania lantanowców w wodach podziemnych w skali kontynentalnej, tj. w Europie, wykorzystano wyniki z opracowania Geochemistry of European bottled water (Reimann, Birke, 2010; Birke i in., 2010). Badania zostały zrealizowane pod auspicjami europejskich służb geologicznych i obejmowały podziemne wody butelkowane z 38 krajów i wody kranowe z 29 państw europejskich. Był to, jak dotąd, najszerzej zakrojony projekt, który miał na celu oznaczenie REE w wodach pitnych. W ramach tego przedsięwzięcia wykonano analizy 884 próbek wód butelkowanych, w tym $40 \mathrm{z}$ obszaru Polski. Wyniki tych analiz mogą być traktowane jako przybliżenie zróżnicowanego chemizmu wód podziemnych (Reimann, Birke, 2010; Birke i in., 2010).

Średnie stężenie REE w wodach butelkowanych pochodzących z państw europejskich przedstawiono na ryc. 7. Dodatkowo w tabeli 4 zamieszczono porównanie średnich stężeń REE w wodach butelkowanych i kranowych w Europie.

Na obszarze UE wody podziemne wydobywane do celów butelkowania jako naturalne wody mineralne oraz wody źródlane podlegaja wymaganiom zawartym w dyrektywach nr 2009/54/EC oraz 98/83/EC. W przepisach tych wyraźnie podkreślono, że niedopuszczalne jest stosowanie procesów uzdatniania wody polegających na modyfikacji naturalnego składu chemicznego wód ujmowanych z warstwy wodonośnej. Dopuszcza się jedynie separację niestabilnych składników, takich jak związki żelaza, siarki, manganu i arsenu, przy zastosowaniu filtracji, dekantacji lub napowietrzania, oraz odgazowanie lub nasycenie wód $\mathrm{CO}_{2}$.

W toku badań stwierdzono, że ponad 65\% spośród badanych 884 rodzajów wód butelkowanych nie było poddanych żadnym procesom uzdatniania, a tylko ok. 4\% przeszło proces usunięcia Fe. Największe stężenia REE stwierdzono w butelkowanych wodach podziemnych z krajów skandynawskich - Norwegii $(n=8)$ i Szwecji $(n=9)-$ oraz krajów środkowej i wschodniej Europy - Rumunii $(n=10)$, Słowacji $(n=17)$ i Czech $(n=11)$. Podwyższona zawartość REE w wodach butelkowanych z tych krajów wynika z lokalnej budowy geologicznej, w której przeważają skały magmowe o dużej zawartości lantanowców.

Znormalizowany rozkład średniego stężenia REE w wodach butelkowanych Europy i Polski charakteryzuje się wzbogaceniem w HREE w stosunku do LREE, co jest typowe między innymi dla wód zawierających znaczny udział wodorowęglanów i węglanów w składzie chemicznym. Średnie stężenia REE w wodach z obszaru Polski wskazują na nieznacznie większe wzbogacenie w MREE i HREE w stosunku do średniej zawartości REE we wszystkich badanych wodach kontynentu europejskiego (ryc. 8). Na podstawie danych opublikowanych przez Reimanna i Birke (2010) można wysunać wniosek, że w wodach o naturalnie wysokiej zawartości $\mathrm{CO}_{2}$ występuje większa koncentracja lantanowców niż w wodach niegazowanych, co wynika z faktu, że wody kwasowęglowe i szczawy mają niższe $\mathrm{pH}$ i są bardziej agresywne w stosunku do różnych faz mineralnych w skałach wodonośnych. 


\begin{tabular}{|c|c|c|c|c|c|c|c|c|c|c|c|c|c|c|c|c|c|c|c|c|c|}
\hline & & 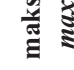 & $\infty$ & f & & $\stackrel{2}{m}$ & 剪 & $n_{0}^{n}$ & $n$ & $\stackrel{\infty}{i}$ & $\sqrt[5]{a}$ & $\mid \begin{array}{c}0 \\
\dot{m}\end{array}$ & 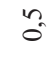 & $\stackrel{n}{i}$ & 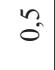 & $\Rightarrow$ & $\because$ & $\stackrel{\circ}{\infty}$ & $\therefore$ & & $\stackrel{g}{I}$ \\
\hline \multirow{7}{*}{ 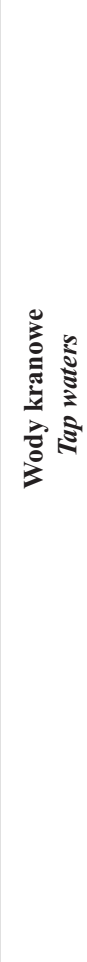 } & \multirow{3}{*}{ 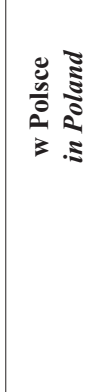 } & 榇 & 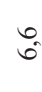 & I & \multirow{3}{*}{ 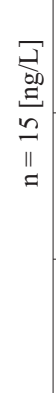 } & ${ }^{n}$ & $a$ & $n$ & $n$ & $\stackrel{n}{0}$ & na & - & 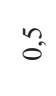 & $\because$ & $\stackrel{n}{0}$ & $\stackrel{n}{a}$ & $\begin{array}{l}n \\
0 \\
0\end{array}$ & ${ }^{n}$ & $a_{0}^{n}$ & $\overline{\mathrm{i}}$ & $\frac{2}{f}$ \\
\hline & & 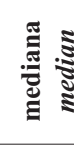 & $\therefore$ & 索 & & त्ञ్ & $\stackrel{\infty}{-\infty}$ & 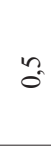 & $\stackrel{\infty}{\rightarrow}$ & $\stackrel{?}{=}$ & 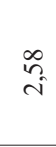 & - & $a_{0}^{n}$ & $\stackrel{5}{=}$ & $n$ & $\stackrel{n}{8}$ & $n$ & $n_{0}$ & $n_{0}$ & 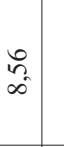 & $\infty$ \\
\hline & & 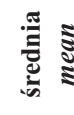 & $\stackrel{+}{\sim}$ & 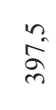 & & $\stackrel{\infty}{=}$ & $\mid \begin{array}{r}a \\
i \\
i\end{array}$ & $n$ & $\tilde{i}_{\tilde{s}}$ & $\stackrel{\infty}{\rightarrow}$ & $\stackrel{r}{q}$ & $\stackrel{\infty}{-\infty}$ & $a$ & $\stackrel{\infty}{=}$ & $a$ & $\begin{array}{l}\infty \\
0 \\
0\end{array}$ & $\begin{array}{l}n \\
0\end{array}$ & $\vec{\sigma}_{-}$ & $a^{n}$ & $\therefore$ & $\mid \begin{array}{c}\infty \\
\infty \\
\infty \\
\infty\end{array}$ \\
\hline & \multirow{4}{*}{ 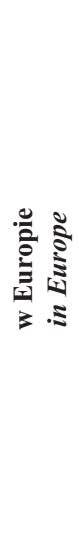 } & 咅 & $\begin{array}{l}0 \\
\infty \\
\infty\end{array}$ & $\stackrel{\bar{\infty}}{=}$ & \multirow{4}{*}{ 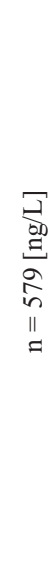 } & 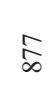 & 高 & $\hat{q}$ & $\stackrel{\circ}{\vec{n}}$ & $\stackrel{\infty}{0}$ & $\stackrel{5}{\circ}$ & $\mid \begin{array}{c}\text { U } \\
\end{array}$ & $\underset{\ddot{\infty}}{\stackrel{\Delta}{*}}$ & $\stackrel{\infty}{+}$ & 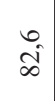 & $\tilde{\text { ก }}$ & $\stackrel{\infty}{\sim}$ & $\stackrel{n}{\underline{B}}$ & वे & ఏి & 总 \\
\hline & & 音音 & $\overrightarrow{6}$ & i & & $\because$ & $a$ & $a$ & 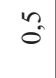 & $\therefore$ & 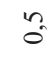 & - & $n$ & $\because$ & $\because$ & $\because$ & $\because$ & 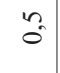 & $a$ & $\because$ & 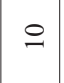 \\
\hline & & 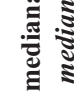 & $\approx$ & 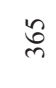 & & $\vec{i}$ & $\stackrel{\infty}{-}$ & $\because$ & $\widetilde{ָ}$ & $\underset{f}{f}$ & $\underset{i}{\tilde{i}}$ & - & $\because$ & $\stackrel{+}{*}$ & $n$ & ${ }_{0}^{n}$ & $\because$ & $\exists$ & $\because$ & $\begin{array}{l}\infty \\
\infty \\
\infty\end{array}$ & 亲 \\
\hline & & 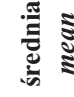 & $\therefore$ & 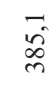 & & $\stackrel{9}{\subseteq}$ & $\approx$ & $\stackrel{b}{i}$ & 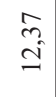 & $\stackrel{\infty}{\infty}$ & t & $\mid$\begin{tabular}{c}
0 \\
\multirow{\jmath}{*}{}
\end{tabular} & $\begin{array}{l}n \\
\hat{0}\end{array}$ & $\overrightarrow{\hat{x}_{0}}$ & $\underset{\substack{\infty \\
\infty \\
\infty}}{0}$ & $\stackrel{\sim}{i}$ & $\mid \begin{array}{l}0 \\
0 \\
0\end{array}$ & 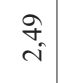 & $\hat{0}$ & 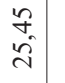 & {$\left[\begin{array}{l}\infty \\
0 \\
0 \\
\infty\end{array}\right]$} \\
\hline \multirow{8}{*}{ 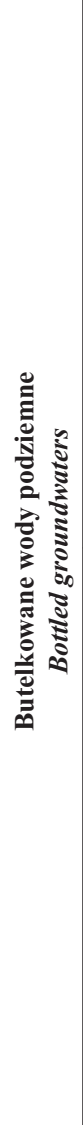 } & \multirow{4}{*}{ 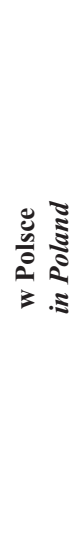 } & 总 & $\begin{array}{c}\tilde{\infty} \\
\infty\end{array}$ & 常 & \multirow{4}{*}{ 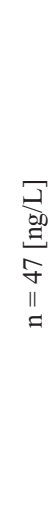 } & $\stackrel{n}{气}$ & q & בे & $\cong$ & 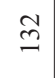 & 年 & $\stackrel{ \pm}{I}$ & $\begin{array}{l}\infty \\
\stackrel{\infty}{0}\end{array}$ & \pm & $\begin{array}{l}0 \\
\text { si } \\
m\end{array}$ & 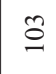 & $\begin{array}{c}\hat{2} \\
\hat{n}\end{array}$ & $\stackrel{ \pm}{\Xi}$ & $\simeq$ & $\stackrel{\bigcirc}{\exists}$ & {$\left[\begin{array}{l}\infty \\
i \\
i n\end{array}\right.$} \\
\hline & & 咅 & $\stackrel{\infty}{\sim}$ & $\stackrel{\sim}{\tilde{\lambda}}$ & & 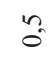 & $a$ & $\because$ & $\because$ & $\because$ & $\because$ & - & $\because$ & $\therefore$ & $\because$ & $\because$ & $\because$ & $\because$ & $\because$ & 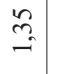 & $\overline{\mathrm{i}}$ \\
\hline & & 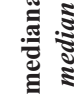 & no & $\underset{\infty}{\mathbf{D}}$ & & ते & $\stackrel{\leftrightarrow}{\stackrel{2}{2}}$ & $a_{0}^{n}$ & $\stackrel{\text { iे }}{\text { aे }}$ & $\stackrel{\bar{\infty}}{-}$ & $\approx$ & 定 & $\because$ & $\stackrel{0}{=}$ & $a_{0}^{n}$ & $a$ & $\begin{array}{l}n \\
0\end{array}$ & $\stackrel{ \pm}{-}$ & 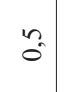 & $\simeq$ & 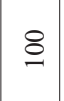 \\
\hline & & 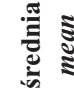 & $0_{0}^{\infty}$ & 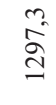 & & $\begin{array}{l}\infty \\
\stackrel{\infty}{\mathbb{I}}\end{array}$ & $\stackrel{\circ}{=}$ & ते & $\stackrel{N}{=}$ & $\stackrel{\circ}{ }$ & $\hat{0}$ & $\begin{array}{l}\stackrel{\circ}{=} \\
=\end{array}$ & $\stackrel{\leftrightarrow}{\rightarrow}$ & $\begin{array}{l}\overrightarrow{\sigma_{0}} \\
\infty\end{array}$ & ঙ̆ & $\hat{\omega}$ & ì & 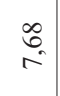 & $\begin{array}{l}\infty \\
\stackrel{\infty}{-} \\
\stackrel{-}{2}\end{array}$ & $\begin{array}{l}\infty \\
\infty \\
\infty \\
0 \\
0\end{array}$ & 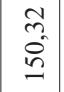 \\
\hline & \multirow{4}{*}{ 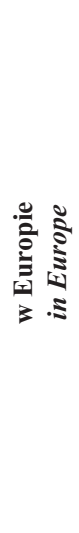 } & $\dot{\underline{g}}$ & $\dot{a}$ & 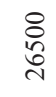 & \multirow{4}{*}{ 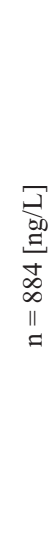 } & $\stackrel{\square}{\circ}$ & $\frac{8}{6}$ & 总 & ì & $\sqrt{6}$ & 导 & ठ & $\approx$ & 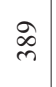 & $\Xi$ & $\mathcal{F}$ & $\bar{\Xi}$ & 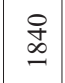 & $\bar{F}$ & 层 & 品 \\
\hline & & 音音 & + & $\stackrel{\infty}{\simeq}$ & & $\because$ & $\because$ & $\because$ & $\because$ & $\because$ & $\because$ & - & $\because$ & $\because$ & $\because$ & $\because n$ & $\because n$ & $\because n$ & $\because$ & $\therefore$ & 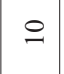 \\
\hline & & 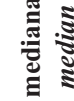 & $\begin{array}{l}\infty \\
0 \\
0 \\
0\end{array}$ & $\begin{array}{c}n \\
\infty \\
\infty \\
n \\
n\end{array}$ & & $\vec{j}$ & an & 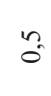 & $\stackrel{t}{i}$ & $\cong$ & ${ }^{n}$ & - & 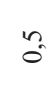 & $\stackrel{ }{\leftrightarrows}$ & 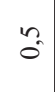 & $\stackrel{n}{0}$ & $\begin{array}{l}n \\
0\end{array}$ & $\because$ & 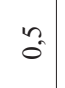 & $\begin{array}{l}\text { I } \\
\beth\end{array}$ & 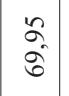 \\
\hline & & 焉 & tó & $\stackrel{f}{\stackrel{f}{I}}$ & & $\begin{array}{l}n \\
\cdots \\
i \\
i\end{array}$ & $\begin{array}{l}\vec{\infty} \\
\vec{i}\end{array}$ & \begin{tabular}{l}
6 \\
\hdashline \\
+
\end{tabular} & $\begin{array}{l}\stackrel{ \pm}{ \pm} \\
\stackrel{=}{=}\end{array}$ & $\overrightarrow{5}$ & बे & $\mid \begin{array}{c}\hat{b} \\
\hat{n}\end{array}$ & $\hat{s}$ & $\begin{array}{l}\infty \\
\stackrel{\sigma}{+}\end{array}$ & $\stackrel{\circ}{-}$ & $\stackrel{\vartheta}{f}$ & $\Rightarrow$ & $\begin{array}{l}0 \\
0 \\
0\end{array}$ & $\stackrel{\hat{n}}{\rightarrow}$ & ". & 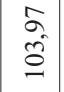 \\
\hline & & & & 品 & 亲 & త & 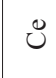 & 2 & $\vec{z}$ & 政 & $\bar{\Psi}$ & $\Xi$ & $\vec{F}$ & $\vec{a}$ & 욱 & 缹 & $\Xi$ & 2 & $\exists$ & $>$ & m \\
\hline
\end{tabular}




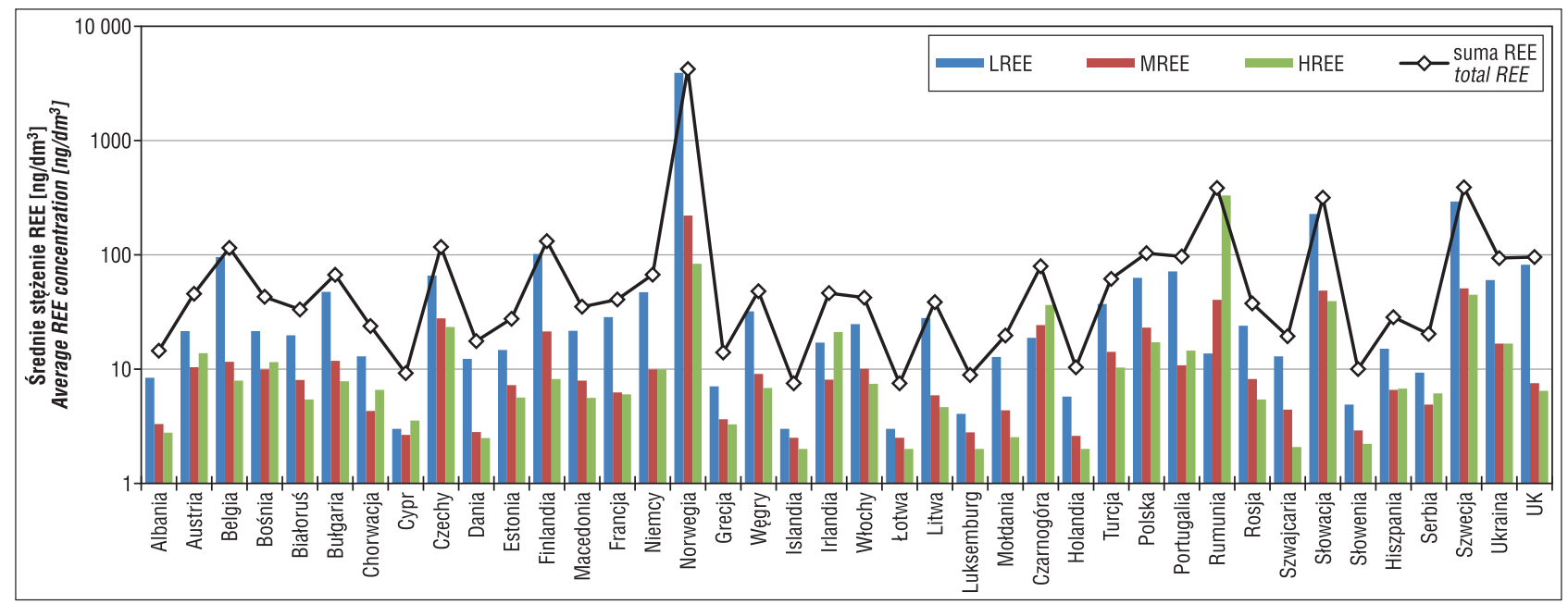

Ryc. 7. Średnie stężenie REE w wodach butelkowanych krajów europejskich jako odzwierciedlenie występowania lantanowców w wodach podziemnych (dane wg Reimanna, Birke, 2010)

Fig. 7. Average PAAS-normalized REE-concentration patterns in bottled water of European countries as a proxy to occurrence of lanthanides in groundwaters (data after Reimann, Birke, 2010)

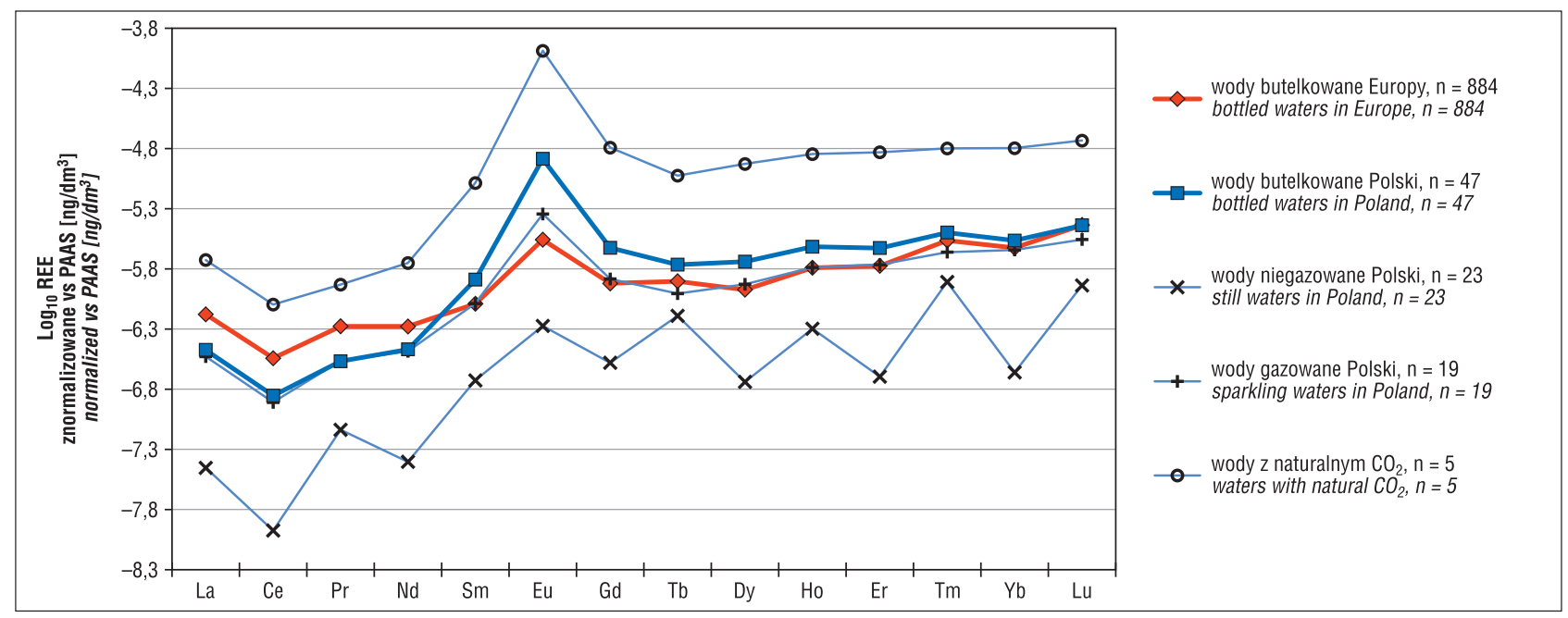

Ryc. 8. Znormalizowany rozkład średniego stężenia REE w butelkowanych wodach podziemnych Polski na tle średniej w krajach europejskich ( $\mathrm{n}=884 \mathrm{z}$ uwzględnieniem Polski; dane wg Reimanna, Birke, 2010)

Fig. 8. Average REE pattern of bottled groundwaters for Poland in comparison to average for other European countries $(n=884$ including Poland; data after Reimann, Birke, 2010)

Niektóre pierwiastki ziem rzadkich występujące w wodach podziemnych są wrażliwe na zmiany warunków geochemicznych środowiska i tym samym często osiagają anomalną zawartość, np. cer (Ce), europ (Eu) i itr (Y). W wodach butelkowanych większości krajów europejskich stwierdzono dodatnią anomalię Eu (Reimann, Birke, 2010), jednak nasuwa się pewna wątpliwość dotycząca tych wyników. Wszystkie oznaczenia zawartości REE w badanych wodach były wykonane za pomocą metody spektrometrii mas z plazmą indukcyjnie wzbudzoną (ICP-MS), która jest szczególnie wrażliwa na występowanie interferencji spektralnych - nakładanie się sygnałów izotopowych od różnych pierwiastków zawartych w próbce (Prohaska i in., 1999; Fisher, Kara, 2016). Oznaczenie stężenia Eu (szczególnie, gdy jest niskie i bliskie granicy wykrywalności metody) może być zawyżone z powodu występowania interferencji spektralnych pochodzących od tlenku baru. Obliczony współczynnik korelacji pomiędzy stężeniem $\mathrm{Ba}$ i Eu w populacji 884 próbek europejskich wód butelkowanych wynosi ok. 0,98 i wskazuje na praw- dopodobieństwo zawyżenia wartości stężenia Eu z powodu wspomnianych interferencji.

\section{REE W WODACH KRANOWYCH}

Wody kranowe są klasyfikowane jako wody pitne, przeznaczone do spożycia przez ludzi, a ich jakość jest regulowana odpowiednimi aktami normatywnymi. Określają one wymagania bakteriologiczne, fizyczne, chemiczne i organoleptyczne, jakie musi spełniać woda pitna. Na obszarze Wspólnoty Europejskiej wymogi odnośnie jakości wody pitnej określają dyrektywy UE 98/83/WE z 3 listopada 1998 r. oraz 2013/51/EURATOM z 22 października 2013 r. W Polsce obowiązującym aktem normatywnym jest Rozporządzenie Ministra Zdrowia z 7 grudnia 2017 r. w sprawie jakości wody przeznaczonej do spożycia przez ludzi. Należy podkreślić, że wymogi dotyczące jakości wód pitnych nie uwzględniają zawartości lantanowców. Ponieważ toksyczność REE nie została dokładnie poznana, a ich stężenie w wodach jest zwykle bardzo niskie, to dotychczas nie podjęto działań mających na celu określenie ich 
dopuszczalnego stężenia w wodzie pitnej. Analiza występowania i sygnatury REE w wodach kranowych dotyczy więc dwóch głównych aspektów: 1) podwyższonej ogólnej sumarycznej zawartości REE oraz 2) obecności anomalii - podwyższonego stężenia pojedynczych pierwiastków z grupy REE, np. Gd jako wskaźnika antropopresji. Występowanie i zawartość REE w wodach kranowych zależą przede wszystkim od trzech czynników: 1) rodzaju ujętej wody - dla sumarycznej zawartości REE znaczenie ma fakt, czy są pozyskiwane z wód podziemnych, czy powierzchniowych; 2) procesów uzdatniania, które mogą wpływać na ostateczne stężenie REE w punkcie odbioru wody ( $\mathrm{tj}$. w kranie); 3) stanu i rodzaju instalacji wodociagowych.

Pilotażowe badania, mające na celu oznaczenie stężenia REE w miejskich wodach kranowych, przeprowadzono w Niemczech i Holandii już w połowie lat 90. XX w. Wyniki badań 7 próbek wody kranowej z Berlina, opublikowane przez Bau i Dulskiego (1996), wykazały podwyższoną zawartość REE i szczególnie wyraźną dodatnią anomalię Gd. Zawartość Gd była największa spośród wszystkich lantanowców i wyniosła maksymalnie $6,25 \mathrm{ng} / \mathrm{L}$. Również w próbkach wody pitnej z Holandii stwierdzono znacznie podwyższoną zawartość REE - np. od 26 do 3791 ng/L gadolinu (De Boer i in., 1996), a stężenia La, Ce i Nd były jeszcze wyższe. Zarówno w wodach pitnych badanych na terenie Niemiec, jak i Holandii, źródłem podwyższonej zawartości REE był czynnik antropogeniczny (środki farmaceutyczne lub nawozy sztuczne). Oznaczenia REE w wodach kranowych na terenie Berlina powtórzono w 2011 i 2014 r. i, jak wskazują opublikowane dane (Kulaksiz, Bau, 2011; Tepe i in., 2014), zawartość REE wzrosła jeszcze w stosunku do pomierzonej w 1996 r. Najbardziej zwiększyła się zawartość gadolinu (maksymalne stężenie wynosiło 27,33 ng/L), który jest stosowany m.in. w postaci kwasu gadopentetowego (GdDTPA) jako środek kontrastujący w badaniach metodą rezonansu magnetycznego.

Wyniki badań przeprowadzonych we Włoszech czy Chorwacji również wykazały relatywnie wysokie stężenie REE w wodach kranowych. We Włoszech suma stężeń lantanowców (La-Lu) mieściła się w przedziale od 2,5 do 1338 ng/L. Największe stężenie REE otrzymano w próbkach wód pobranych na Sardynii, w regionie TrydentGórna Adyga, na Sycylii oraz w Lacjum. W wodach krano- wych w Chorwacji podwyższona sumaryczna zawartość REE wahała się w przedziale od $102 \mathrm{ng} / 1$ do $313 \mathrm{ng} / \mathrm{L}$ (Fiket i in., 2015). W odróżnieniu od Niemiec i Holandii większa zawartość REE w wodach Włoch i Chorwacji ma pochodzenie geogeniczne. Na przykład w środkowej części Włoch jest ona związana z kwaśnymi skałami magmowymi, na Sardynii i w Trydencie - z zasadowymi skałami wulkanicznymi, a na Sycylii i Sardynii ze skałami metamorficznymi (Dinelli i in., 2012). Zróżnicowanie stężenia REE w wodach kranowych krajów europejskich przedstawiono na ryc. 9. Wykres przygotowano na podstawie danych opublikowanych w monografii Geochemistry of European bottled water (Reimann, Birke, 2010).

Średnie stężenie REE w pitnych wodach kranowych pobranych w 29 krajach Europy, w tym w Polsce, ilustruje rycina 10A. Rozkład REE znormalizowany względem PAAS, uzyskany na podstawie danych zawartych w opracowaniu Geochemistry of European bottled water (Reimann, Birke, 2010), nie wskazuje na występowanie anomalnie podwyższonej zawartości Gd. W badanych wodach kranowych, podobnie jak w podziemnych wodach butelkowanych, uwidacznia się za to dodatnia anomalia Eu. Trudno jest wytłumaczyć różnicę pomiędzy stężeniami Gd i Eu uzyskanymi w różnych szczegółowych badaniach REE w wodach kranowych europejskich aglomeracji miejskich (Kulaksiz, Bau, 2011; Tepe i in., 2014) i danymi opublikowanymi w monografii pod redakcją Reimanna i Birke (2010).

Wyniki badań warszawskich wód kranowych potwierdzają obecność dodatniej anomalii Gd i brak anomalii Eu (Rogowska i in., 2018). Obecnie w Warszawie funkcjonują trzy zakłady uzdatniania wody: Zakład Centralny i Zakład Praski wykorzystują wodę z Wisły, natomiast Zakład Północny ujmuje wody Jeziora Zegrzyńskiego. W częściach miasta, gdzie woda kranowa pochodzi z uzdatnionej wody wiślanej (np. w dzielnicy Mokotów), obserwuje się niewielkie podwyższenie stężenia wszystkich lantanowców (suma stężeń REE wynosi ok. 32 ng/L) i wyraźnie zaznaczoną dodatnią anomalię Gd (ryc. 10B). W przypadku wód kranowych pochodzących z Jeziora Zegrzyńskiego (np. dzielnica Targówek) zawartość wszystkich lantanowców jest wyraźnie mniejsza (suma stężeń REE wynosi ok. $8 \mathrm{ng} / \mathrm{L}$ ), ale wciąż zaznacza się dodatnia anomalia gadolinu, co świad-

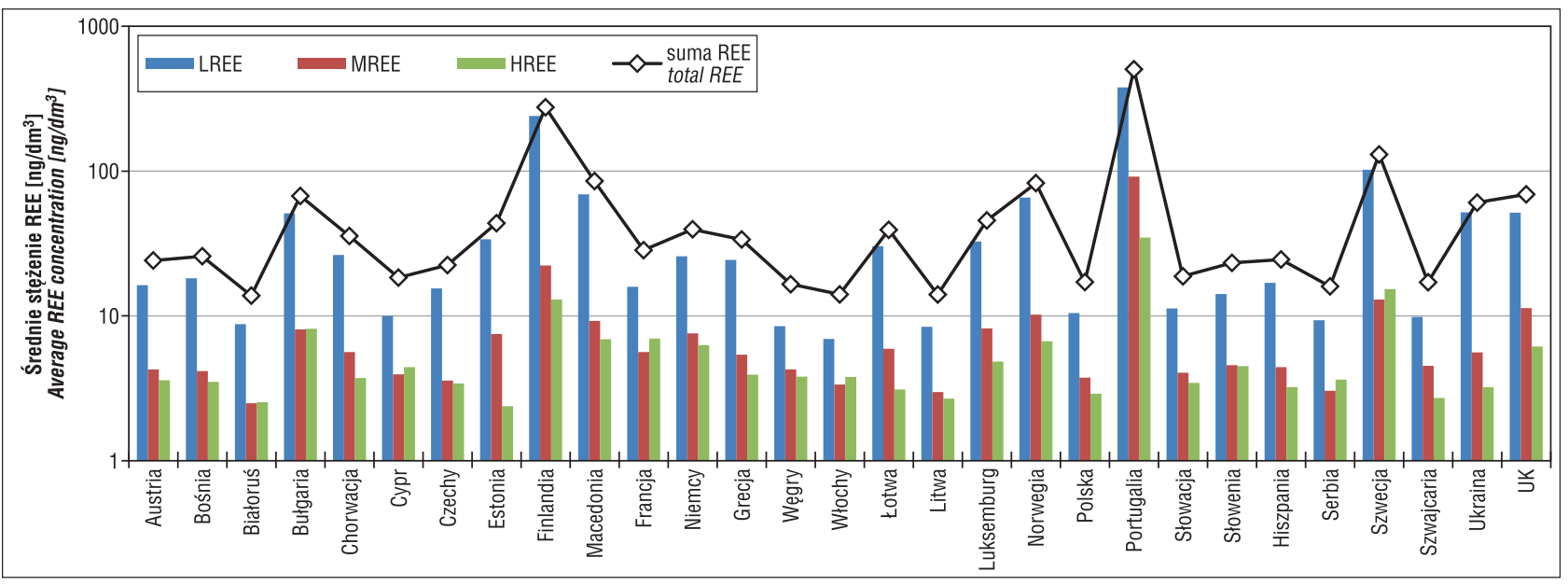

Ryc. 9. Średnie stężenie LREE, MREE i HREE oraz sumaryczna zawartość REE w wodach kranowych państw europejskich (dane wg Reimanna, Birke, 2010)

Fig. 9. Average concentrations of LREE, MREE and HREE, and sum of REE contents in tap waters of European countries (data after Reimann, Birke, 2010) 


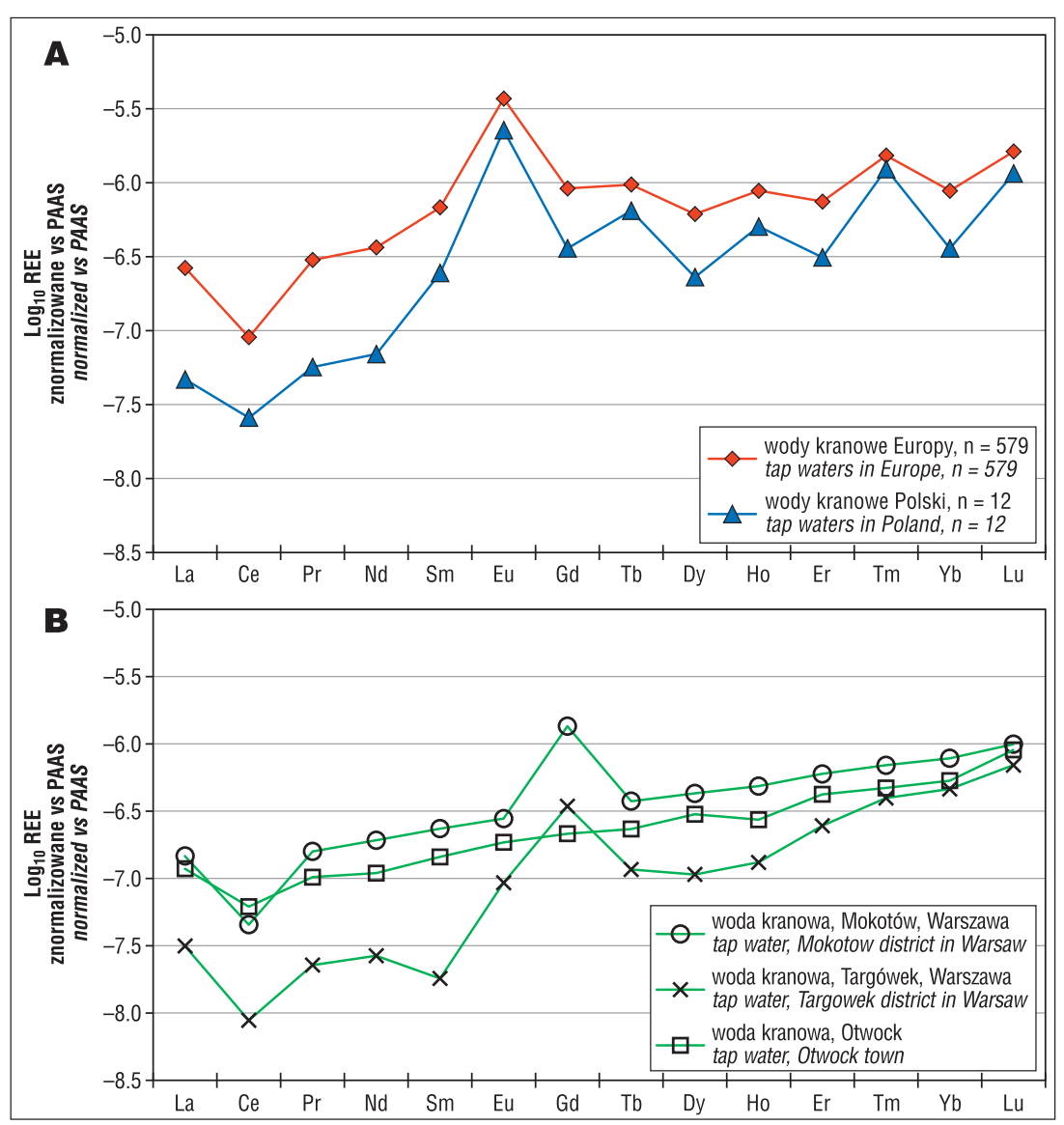

\section{$\leftarrow$}

Ryc. 10. Znormalizowany rozkład średniej zawartości REE w wodach pitnych kranowych Polski na tle Europy (A) - dane wg Reimanna i Birke, 2010; (B) - rozkład zawartości REE w wodach kranowych aglomeracji warszawskiej (dane wg Rogowskiej i in., 2018)

Fig. 10. Average PAAS-normalized REE concentration patterns for tap waters in Poland in comparison to European countries (A) - data after Reimann and Birke, 2010; (B) - REE patterns for tap waters in Warsaw agglomeration (data after Rogowska et al., 2018)

czasu, jednak nie mogły być one rozpoznane ze względu na brak odpowiednich metod analitycznych, umożliwiających ich wykrycie i oznaczenie. Przykładem, który warto tutaj przytoczyć, są związki organiczne gadolinu (Gd), które ze względu na właściwości paramagnetyczne znalazły zastosowanie w medycynie i od 1988 r. są z powodzeniem wykorzystywane jako środki kontrastujące w badaniach metodą rezonansu magnetycznego. Ponieważ związki kompleksowe Gd są bardzo trwałe i nie ulegaja degradacji $\mathrm{w}$ procesie uzdatniania wody, zaobserwowano, że zawartość

czy o wpływie zanieczyszczeń antropogenicznych. Woda kranowa ujmowana ze studni głębinowej w Otwocku nie wykazuje dodatniej anomalii gadolinu, a zawartość REE odzwierciedla poziom naturalny dla wód podziemnych (suma stężeń REE wynosiła ok. $21 \mathrm{ng} / \mathrm{L}$ ).

\section{ZANIECZYSZCZENIE ŚRODOWISKA A REE}

Ze względu na rosnący popyt na pierwiastki krytyczne i szerokie zastosowanie REE w przemyśle wysokotechnologicznym, bezpośredni kontakt człowieka z substancjami zawierającymi podwyższone stężenie REE stale wzrasta. Toksyczność REE jest określana na poziomie niskim lub średnim. Jednak obserwacje i badania naukowe dowodzą, że mają one niekorzystny wpływ na organizmy żywe w przypadku ich długotrwałego narażenia na działanie REE o wyraźnie podwyższonej koncentracji.

Pierwiastki ziem rzadkich są uruchamiane ze skał w wyniku procesów naturalnych, takich jak wietrzenie skorupy kontynentalnej lub na skutek intensywnej działalności człowieka, takiej jak: wydobycie kopalin, przeróbka rud i skał oraz produkcja przemysłowa. Przedostawanie się większych ilości REE do środowiska powoduje zanieczyszczenie powietrza, wody, gleb i osadów. W ostatnich latach REE zostały zakwalifikowane do grupy tzw. nowych zanieczyszczeń (emerging contaminants), które wcześniej nie były obserwowane w środowisku. Źródłem ich pochodzenia są m.in. nawozy sztuczne, ścieki komunalne i przemysłowe oraz w wielu przypadkach działalność górnicza. Ponieważ REE przedostają się zarówno do środowiska lądowego, jak i morskiego, mogą powodować niekorzystne skutki ekologiczne, a także zdrowotne u ludzi i zwierząt. W niektórych przypadkach te nowe i niepożądane substancje chemiczne były emitowane do środowiska już od pewnego gadolinu w niektórych wodach powierzchniowych jest większa w porównaniu do zawartości pozostałych pierwiastków z grupy lantanowców (Hatje i in., 2016). Badania przeprowadzone w krajach rozwiniętych (np. Niemcy, Czechy, Wielka Brytania i USA), zapewniających wysoki standard usług medycznych, pokazały, że związki gadolinu są obecne także w wodach kranowych (Bau, Dulski, 1996; Kulaksiz, Bau, 2011; Möller i in., 2002; Hatje i in., 2016). Problem ten dotyczy szczególnie dużych metropolii, w których miejskie przedsiębiorstwa wodne korzystają głównie z powierzchniowych ujęć wody (np. rzek i jezior). W takiej sytuacji skład chemiczny wody pitnej zależy w dużym stopniu od jakości wód powierzchniowych ujmowanych do celów komunalnych.

Innym ważnym źródłem przedostawania się REE do środowiska są wody kopalniane: głównie wody drenażowe i kwaśne odcieki poflotacyjne związane z przeróbką rud i skał. Problem ten jest dość szeroko poruszany w najnowszej literaturze światowej, np. Olias i in. (2005), Romero $i$ in. (2010), Delgado i in. (2012) oraz Grawunder i in. (2014). W Polsce problematyką kwaśnych wód kopalnianych zajmuje się Migaszewski z zespołem (Migaszewski i in., 2016). Kwaśne odcieki z kopalń są silnie wzbogacone w REE i stanowią duże źródła zanieczyszczeń tak wód powierzchniowych, jak i podziemnych. Przy czym mogą one funkcjonować jeszcze przez długi czas po zakończeniu działalności górniczej i są trudne do likwidacji.

\section{PODSUMOWANIE}

Ze względu na podobieństwo budowy atomów REE, a w konsekwencji ich właściwości fizyczno-chemicznych, mają one unikalne znaczenie zarówno w gospodarce i przemyśle, jak i w badaniach naukowych. Oznaczenie zawarto- 
ści REE i ich sygnatury w skałach, minerałach i wodach może być stosowane do wyjaśniania procesów geochemicznych zachodzących w skorupie ziemskiej i środowisku.

Chociaż badania zawartości REE w różnych typach wód są prowadzone na świecie od dziesięcioleci to wykonanie ich dokładnych pomiarów wciąż stanowi duże wyzwanie analityczne. Metodą, którą obecnie najczęściej wykonuje się oznaczenia niskich stężeń REE w próbkach wód, jest ICP-MS, jednak jej stosowanie wymaga zwrócenia szczególnej uwagi na potencjalny wpływ pierwiastków głównych na wyniki analiz REE. Niskie stężenie REE w wodach naturalnych niezanieczyszczonych ( ng/L lub poniżej) i obecność dużego nadmiaru innych substancji chemicznych moga wpływać na dokładność i wiarygodność wyników. Przykładami pierwiastków, które sprawiają najwięcej problemów analitycznych, są europ, samar i skand. Anomalnie podwyższone oznaczenia zawartości $\mathrm{Eu}$ w wodach mogą być następstwem wpływu interferencji tlenków baru na wyniki analiz (Prohaska i in., 1999).

Najmniejsza koncentracja REE występuje w wodach mórz i oceanów oraz w niektórych wodach podziemnych. Dane dotyczące zawartości REE w wodach kranowych krajów europejskich świadczą o mniejszym zróżnicowaniu stężenia REE w tych wodach niż w wodach podziemnych. Minimalna średnia suma zawartości REE w wodach kranowych wynosiła ok. 14 ng/L na Białorusi, a maksymalna ok. $505 \mathrm{ng} / \mathrm{L}$ w Portugalii. W wodach podziemnych Europy (reprezentowanych przez 884 próbki butelkowanych wód mineralnych; Reimann, Birke, 2010) najwyższe stężenia REE oznaczono w próbkach wód z Norwegii. Suma stężeń REE wyniosła ok. 4200 ng/L, tj. ok. 40 razy więcej niż w Polsce i ok. 400 razy więcej niż w wodach Albanii, Czech, Islandii, Łotwy i Słowenii. Główny wpływ na tak ogromne zróżnicowanie zawartości REE w wodach podziemnych ma rodzaj skały macierzystej zbiornika wodonośnego. Słodkie wody powierzchniowe oraz podziemne charakteryzują się znacznie większym zróżnicowaniem zawartości REE w porównaniu do oceanów. W wodach rzecznych Europy średnie stężenie REE jest ok. 10 razy większe niż w wodach Polski. Natomiast średnia zawartość REE w wodach strumieni na obszarze Europy jest ok. 100000 razy mniejsza niż w osadach strumieniowych (Salminen i in., 2005). Największe stężenia REE w wodach strumieniowych Europy stwierdzono w Szwecji i Finlandii (średnia suma REE powyżej $10000 \mathrm{ng} / \mathrm{L}$ ), natomiast najmniejsze w Albanii, Grecji i Słowenii (suma REE poniżej $100 \mathrm{ng} / \mathrm{L})$.

$\mathrm{Na}$ zawartość REE w wodach powierzchniowych wpływają zarówno źródła naturalne, jak i antropogeniczne. Źródła antropogeniczne mają znaczenie drugorzędne, jednak mogą odgrywać istotną rolę w depozycji REE w wodach. Podobnie jak w przypadku gleb, REE dostarczane do innych elementów środowiska przyrodniczego moga oddziaływać na organizmy żywe. Najważniejszymi antropogenicznymi źródłami REE w wodach są: nawozy sztuczne (fosforowe, produkowane $\mathrm{z}$ naturalnych fosforanów o stosunkowo dużej zawartości REE); popioły ze spalania odpadów i węgla; szlamy, osady i wody ściekowe; ścieki przemysłowe i komunalne oraz wody kopalniane (głównie wody drenażowe i kwaśne odcieki poflotacyjne związane z przeróbką rud i skał). Na zawartość REE w wodach powierzchniowych może mieć także wpływ depozycja REE z atmosfery (pyły, cząstki, deszcz, śnieg). Zawartość REE w atmosferze jest zależna od obciążenia antropogenicznego, szczególnie w pobliżu miast. Podwyższona zawartość niektórych lantanowców (La, Ce, Sm, Eu,
Tb) w atmosferze nad obszarami przemysłowymi i miejskimi świadczy o ich pochodzeniu antropogenicznym, czego przykładem może być wzrost zawartości La z ok. $1 \mathrm{pg} / \mathrm{m}^{3}$ nad biegunem południowym do $3000 \mathrm{pg} / \mathrm{m}^{3}$ nad miastami USA (Kabata-Pendias, Pendias, 1999). Obserwowana w wodach powierzchniowych i kranowych dużych miast dodatnia anomalia gadolinu jest szczególnym przykładem działalności człowieka, a jej głównym źródłem są ścieki komunalne.

Autorzy składają podziękowania Recenzentom za cenne uwagi merytoryczne oraz Redakcji za wskazówki pozwalające udoskonalić formę artykułu. Niniejsza praca powstała w ramach realizacji projektu badawczego nr UMO-2015/17/B/ST10/03295, finansowanego przez Narodowe Centrum Nauki (NCN).

\section{LITERATURA}

AIDE M.T., AIDE C. 2012 - Rare Earth Elements: Their importance and in understanding soil genesis. Intern. Scholar. Res. Network Soil Sci., 12: 1-11. ALIBO D.S., NOZAKI Y. 1999 - Rare earth elements in seawater: particle association, shale-normalization and Ce oxidation. Geochim. Cosmochim. Acta, 63: 363-372.

BAU M., DULSKI P. 1996 - Anthropogenic origin of positive gadolinium anomalies in river waters. Earth and Planetary Sci. Lett., 143 (1): 245-255. BIRKE M., DEMETRIADES A., DE VIVO B. (red.) 2010 - Mineral Waters of Europe. J. Geochem. Explor., 107 (3): 217-422.

CONNELLY N.G., DAMHUS T., HARTSHORN R.M., HUTTON A.T. (red.) 2005 - Nomenclature of inorganic chemistry: IUPAC recommendations 2005. RSC, Cambridge: 377.

DEBAAR H.J.W., BACON M.P., BREWER P.G., BRULAND K.W. 1983 - Rare earth distributions with a positive Ce anomaly in the western Atlantic Ocean. Nature, 301: 324-327.

DEBAAR H.J.W., GERMAN C.R., ELDERFIELD H., VAN GAANS P. 1988 - Rare earth elements distributions in anoxic waters of the Cariaco Trench. Geochim. Cosmochim. Acta, 52: 1203-1219.

DE BOER J.L.M., VERWEIJ W., VAN DER VELDE-KOERTS T., MENNES W. 1996 - Levels of rare earth elements in Dutch drinking water and its sources. Determination by inductively coupled plasma mass spectrometry and toxicological implications. A pilot study. Water Res., 30 (1): 190-198.

DELGADO J., PÉREZ-LÓPEZ R., GALVÁN L., NIETO J.M., BOSKI T. 2012 - Enrichment of rare earth elements as environmental tracers of contamination by acid mine drainage in salt marshes: a new perspective. Marine Pollut. Bull., 64 (9): 1799-1808.

DENG Y., REN Y., GUO Q., CAO J., WANG H., LIU C. 2017 - Rare earth element geochemistry characteristics of seawater and porewater from deep sea in western Pacific. Scientific Reports, 7 (16539): 1-13.

DINELLI E., LIMA A., ALBANESE S., BIRKE M., CICCHELLA D., GIACCIO L., VALERA P., DE VIVO B. 2012 - Major and trace elements in tap water from Italy. J. Geochem. Explor., 112: 54-75.

ELDERFIELD H., GREAVES M.J. 1982 - The rare earth elements in seawater. Nature, 296: 214-219.

FIKET Ź., ROŹMARIĆ M., KRMPOTIĆ M., BENEDIK L. 2015 - Levels of major and trace elements, including rare earth elements, and ${ }^{238} \mathrm{U}$ in Croatian tap waters. Environ. Sci. Pollut. Res. Int., 22 (9): 6789-6799.

FISHER A., KARA D. 2016 - Determination of rare earth elements in natural water samples - A review of sample separation, preconcentration and direct methodologies. Anal. Chim. Acta, 935: 1-29.

GOLDSTEIN S.J., JACOBSEN S.B. 1988 - REE in the Great Whale River estuary, northwest Quebec. Earth and Planet. Sci. Lett., 88: $241-252$.

GRAWUNDER A., MERTEN D., BÜCHEL G. 2014 - Origin of middle rare earth element enrichment in acid mine drainage-impacted areas. Environ. Sci. Pollut. Res., 21 (11): 6812-6823.

HANSON G.N., 1980 - Rare earth elements in petrogenetic studies of igneous systems. Ann. Rev. Earth and Planet. Sci., 8: 371-406.

HASKIN L.A., HASKIN M.A., FREY F.A., WILDEMAN T.R. $1968-$

Relative and absolute terrestrial abundances of the rare earths. [W:] Ahrens LH (red.), Origin and distribution of the elements. Pergamon, 1: 889-912.

HATJE V., BRULAND K.W., FLEGAL A.R. 2016 - Increases in Anthropogenic Gadolinium Anomalies and Rare Earth Element Concentrations in San Francisco Bay over a 20 Year Record. Environ. Sci. Technol., 50: 4159-4168.

HAXEL G.B., HEDRICK J.B., ORRIS G.J. 2002 - Rare Earth Elemnts Critical resources for high technology. USGS Fact Sheet, 087-02: 1-4. 
HOSHINO M., SANEMATSU K., WATANABE Y. 2016 - REE mineralogy and resources. [W:] Bünzli J-Ch., Pecharsky V.K. (red.), Handbook on the physics and chemistry of Rare Earths, 49: 129-291.

JOHANNESSON K.H., STETZENBACH K.J., HODGE V.F. 1997a Rare earth elements as geochemical tracers of regional in groundwater mixing. Geochim. Cosmochim. Acta, 61: 3605-3618.

JOHANNESSON K.H., STETZENBACH K.J., HODGE V.F., KREAMER D.K. 1997b - Delineation of groundwater flow systems in the southern Great Basin using aqueous rare earth elements distributions. Ground Water, 35: 807-819.

JOHANNESSON K.H., FARNHAM I.M., GUO C., STETZENBACH K. J. 1999 - Rare earth fractionation and concentration variations along a groundwater flow path within a shallow, basin-fill aquifer, southern Nevada, USA. Geochim. Cosmochim. Acta, 63: 2697-2708.

JOHANNESSON K.H., XIAOPING Z., CAIXIA G., STETZENBACH K.J., VERNON F.H. 2000 - Origin of rare earth elements signatures in groundwaters of circumneutral $\mathrm{pH}$ from southern Nevada and eastern California, USA. Chemical Geol., 164: 239-257.

KABATA-PENDIAS A., PENDIAS H. 1999 - Biogeochemia pierwiastków śladowych, PWN, Warszawa: 398.

KRZEMIŃSKA E., KRZEMIŃSKI L. 2012 - Alkaliczna intruzja syenitowa Mławy a perspektywy występowania pierwiastków ziem rzadkich. Biul. PIG, 448 (2): 401-410.

KUBICKI S., RYKA W. 1984 - Późnoprekambryjski magmatyzm platformowy i karbonatyty w polskiej części platformy wschodnioeuropejskiej. Prz. Geol., 5: 252-259.

KULAKSIZ S.M., BAU M. 2011- Anthropogenic gadolinium as a microcontaminant in tap water used as drinking water in urban areas and megacities. Appl. Geochem., 26: 1877-1885.

KWECKO P. 2016a - Rare earth elements (REE) and thorium in the youngest Pleistocene glacial tills in Poland. Geol. Quart., 60: 451-460.

KWECKO P. 2016b - Pierwiastki ziem rzadkich (REE) w środowiskach powierzchniowych litosfery. Prz. Geol., 64 (11): 902-917.

LEWIS A.J., KOMNINOU A., YARDLEEY B.W.D, PALMER M.R. 1998 - Rare earth speciation in geothermal fluids from Yellowstone National Park, Wyoming, USA. Geochim. Cosmochim. Acta, 62: 657-663.

LIDE D.R. (red.) 2004 - CRC Handbook of chemistry and physics. $84^{\text {tt }}$ Edition, CRC Press LLC: 2475

LUO Y.R., BYRNE R.H. 2004 - Carbonate Complexation of Yttrium and the Rare Earth Elements in Natural Waters. Geochim. Cosmochim. Acta, 68 (4): 691-699.

MCLENNAN S.M. 1989 - Rare earth elements in sedimentary rocks influence of provenance and sedimentary processes. Rev. Miner. Geochim., 21: 169-200.

MICHARD A., ALBAREDE F. 1986 - The REE contents of some hydrothermal fluids. Chem. Geol., 55: 51-60.

MIGASZEWSKI Z.M., GAŁUSZKA A., MIGASZEWSKI A. 2014

The study of rare earth elements in farmer's well waters of the Podwiśniówka acid mine drainage area (south-central Poland). Environ. Monit. Asses., 186: 1609-1622.

MIGASZEWSKI Z.M., GAŁUSZKA A., DOŁĘGOWSKA S., HAŁAS S. KRZCIUK K., GEBUS B. 2015 - Assessing the impact of Serwis mine tailings site on farmers' wells using element and isotope signatures (Holy Cross Mountains, south-central Poland). Environ. Earth Sci., 74 (1): 629-647. MIGASZEWSKI Z.M., GAŁUSZKA A., DOŁEGOWSKA S. 2016 Rare earth and trace element signatures for assessing an impact of rock mining and processing on the environment: Wiśniówka case study, south-central Poland. Environ. Sci. Pollut. Res., 23 (24): 24943-24959. MIGASZEWSKI Z.M., GAŁUSZKA A. 2016 - The use of gadolinium and europium concentrations as contaminant tracers in the Nida River watershed in south-central Poland, Geol. Quart., 60 (1): 65-74.

MIKULSKI S.Z., KRAMARSKA R., ZIELIŃSKI G. 2016 - Rare earth elements pilot studies of the Baltic marine sands enriched in heavy minerals. Gosp. Sur. Miner., 32 (4): 5-28.

MÖLLER P. 2002a-The distribution of rare earth elements and yttrium in water-rock interactions: field observations and experiments. [W:] Stober I., Bucher K. (red.), Water-rock interaction. Kluwer Academic Publish. Dordrecht, The Nederlands, 40: 97-123.

MÖLLER P. 2002b - Rare earth elements and yttrium in geothermal fluids. [W:] Stober I.B. (red.), Water Sci. Technol. Libr., 40: 97-125.

MÖLLER P., DULSKI P., MORTEANI G. 2003a - Partitioning of rare earth elements, yttrium, and some major elements among source rocks, liquids and vapor of Larderello-Travale Geothermal field, Tuscany (Central Italy). Geochim. Cosmochim. Acta, 67: 171-183.

MÖLLER P., PACES T., DULSKI P., MORTEANI G. 2002 - Anthropogenic Gd in Surface Water, Drainage System, and the Water Supply of the City of Prague, Czech Republic. Environ. Sci. Technol. 11: 2387-2394. MÖLLER P., ROSENTHAL E., DULSKI P., GEYERC S., GUTTMAND Y. 2003b - Rare earths and yttrium hydrostratigraphy along the Lake Kinneret-Dead Sea-Arava transform fault, Israel and adjoining territories. Appl. Geochem., 18: 1613-1628.
MÖLLER P., DULSKI P., SAVASCIN Y. 2004 - Rare earth elements yttrium and $\mathrm{Pb}$ isotope ratios in thermal spring and well waters of West Anatolia, Turkey: a hydrochemical study of their origin. Chem. Geol., 206: 97-118.

MÖLLER P., WEISE S.M., TESMER M., DULSKI P., PEKDEGER A., BAYER U., MAGRI F. 2008 - Salinization of groundwater in the North German Basin: results from conjoint investigation of major, trace element and multi-isotope distribution. Intern. J. Earth Sci., 97: 1057-1073. NEAL C., ROBSON A.J. 2000 - A summary of river water quality data collected within the Land - Ocean Interaction Study: core data for eastern UK rivers draining to the North Sea. Sci. Total Environ., 251/252: 585-665.

NOACK C.W., DZOMBAK D.A., KARAMALIDIS A.K. 2014 - Rare earth element distributions and trends in natural waters with a focus on groundwater. Environ. Sci. Technol., 48: 4317-4326.

OLÍAS M., CERON J.C., FERNÁNDEZ I., DE LA ROSA J. 2005 Distribution of rare earth elements in an alluvial aquifer affected by acid mine drainage: the Guadiamar aquifer (SW Spain). Environ. Pollut., 135 (1): 53-64.

PAULO A. 1993 - Dlaczego nie należy poszukiwać złóż rud niobu i pierwiastków ziem rzadkich w Polsce. Pol. Tow. Miner., Pr. Spec., 3: 55-77. PIEPGRAS D.J., JACOBSEN S.B. 1992 - The behavior of rare earth elements in seawater: precise determination of variations in the North Pacific water column. Geochim. Cosmochim. Acta, 56: 1851-1862.

POROWSKI A., KACZOR-KURZAWA D. 2016 - Pierwiastki ziem rzadkich (REE) w wodach termalnych: występowanie, pochodzenie, znaczenie i perspektywy badań w Polsce. Techn. Poszuk. Geol., Geotermia, Zrównoważony Rozwój, 55 (1): 89-102.

PROHASKA T., HANN S., LATKOCZY C., STINGEDER G. $1999-$ Determination of rare earth elements $U$ and $T h$ in environmental samples by inductively coupled plasma double focusing sector field mass spectrometry (ICP-SMS), J. Anal. At. Spectrom., 14: 1-8.

REIMANN C., BIRKE M. 2010 - Geochemistry of European bottled water. Borntraeger Sci. Publ., Stuttgart, 268.

ROGOWSKA A.M., KUTYŁA-OLESIUK A., WYSOCKA I.A. 2018 Lantanowce jako wskaźnik zanieczyszczeń antropogenicznych obecnych w warszawskiej wodzie kranowej. Analityka: Nauka i praktyka. 2: 44-49. ROMERO F.M., PROL-LEDESMA R.M., CANET C., ALVARES L.N., PÉREZ-VÁZQUEZ R. 2010 - Acid drainage at the inactive Santa Lucia mine, western Cuba: Natural attenuation of arsenic, barium and lead, and geochemical behavior of rare earth elements. Appl. Geochem., 25 (5): 716-727.

RYKA W. (red.) 1992 - Geology of Tajno massif (northeastern Poland). Pr. Państw. Inst. Geol., 139.

SALMINEN R. (red.) 2005 - Geochemical Atlas of Europe. Part 1 Background Information, Methodology and Maps. FOREGS.

SCHIJF J., CHRISTENSON E.A., BYRNE R.H. 2015 - YREE scavenging in seawater: A new look at an old model. Marine Chem., 177: 460-471. SCHNETZLER C.C., PHILPOTTS J.A. 1968 - Partitioning coefficients of rare-earth elements and barium between igneous matrix material and rock-forming mineral phenocrysts, [W:] Ahrens L.H. (red.), Origin and distribution of the elements, Pergamon, 1: 929-938.

SCHNETZLER C.C., PHILPOTTS J.A. 1970 - Partitioning coefficients of rare-earth elements between igneous matrix material and rock-forming mineral phenocrysts, II. Geochim. Cosmochim. Acta, 34: 331-340.

SMEDLEY P.L. 1991 - The geochemistry of rare earth elements in groundwater from the Carnmenellis area, southwest England. Geochim. Cosmochim. Acta, 55: 2767-2779.

TANG J., JOHANNESSON K.H. 2003 - Speciation of rare earth elements in natural terrestrial waters: assessing the role of dissolved organic matter from the modeling approach. Geochim. Cosmochim. Acta, 67: 2321-2339.

TANG J., JOHANNESSON K.H. 2006 - Controls on the geochemistry of rare earth elements along a groundwater flow path in the Carrizo Sand aquifer, Texas, USA. Chem. Geology, 255: 156-171.

TEPE N., ROMERO M., BAU M. 2014 - High-technology metals as emerging contaminants: Strong increase of anthropogenic gadolinium levels in tap water of Berlin, Germany, from 2009 to 2012. Appl. Geochem., 45: 191-197.

VOLKER Z. 2013 - Rare Earth Elements. A new approach to the nexus of supply, demand and use: Exemplified along the use of Neodymium in permanent magnets. Springer Thesis Series. Springer-Verlag, Berlin Heidelberg: 157.

WYSOCKA I., VASSILEVA E. 2017 - Method validation for high resolution sector field inductively coupled plasma mass spectrometry determination of the emerging contaminants in the open ocean: Rare earth elements as a case study. Spectrochim. Acta, Part B, 128: 1-10.

YANG J., HALEY B. 2016 - The profile of the rare earth elements in the Canada Basin, Arctic Ocean. Geochem., Geophys., Geosys., 17: 3241-3253. ZHANG J., ZHAO B. 2016 - Separation hydrometallurgy of Rare Earth Elements. Springer Intern. Pub., Switzerland.

Praca wpłynęła do redakcji 20.07.2018 r.

Akceptowano do druku 20.09.2018 r. 